\title{
Platform Dedicated to Nature-Based Solutions for Risk Reduction and Environmental Issues in Hilly and Mountainous Lands
}

\author{
Audrey Baills*(D), Manuel Garcin (1) and Séverine Bernardie
}

check for

updates

Citation: Baills, A.; Garcin, M.; Bernardie, S. Platform Dedicated to Nature-Based Solutions for Risk Reduction and Environmental Issues in Hilly and Mountainous Lands. Sustainability 2021, 13, 1094. https://doi.org/10.3390/su13031094

Received: 8 December 2020

Accepted: 12 January 2021

Published: 21 January 2021

Publisher's Note: MDPI stays neutral with regard to jurisdictional claims in published maps and institutional affiliations.

Copyright: (C) 2021 by the authors. Licensee MDPI, Basel, Switzerland. This article is an open access article distributed under the terms and conditions of the Creative Commons Attribution (CC BY) license (https:/ / creativecommons.org/licenses/by/ $4.0 /)$.
Risk and Prevention Division, BRGM-French geological Survey, 45100 Orléans, France; m.garcin@brgm.fr (M.G.); s.bernardie@brgm.fr (S.B.)

* Correspondence: a.baills@brgm.fr; Tel.: +33-238-644-897

\begin{abstract}
In the context of global changes, nature-based solutions (NBSs) increasingly draw attention as a possible way to reduce disaster risk associated with extreme hydro-meteorological events while providing human well-being and biodiversity benefits at the same time. The PHUSICOS platform is dedicated to gather and analyse relevant NBSs used to reduce disaster risk associated with extreme hydro-meteorological events in mountainous and hilly lands. To design the platform, an in-depth review of 11 existing platforms has been performed. The PHUSICOS platform currently references 152 literature NBS cases and is continuously enriched through the contribution of NBS community. The platform also proposes a qualitative assessment of the NBSs collected according to 15 criteria related with five ambits: "disaster risk reduction", "technical and economical feasibility", "environment", "society", and "local economy". This paper presents the structure of the platform and a first analysis of its content.
\end{abstract}

Keywords: database; disaster prevention; disaster risk reduction (DRR); climate change adaptation (CCA); stakeholders; nature-based solutions (NBS); mountain; hydro-meteorological risks; eco-DRR; ecosystem-based adaptation (EbA)

\section{Introduction \\ 1.1. Context and Needs}

Climate change affects risk profiles all over the world [1]. It also affects mountainous areas and associated risks (landslides, floods, torrential floods, avalanches, etc.) [2]. In the context of climate change, nature-based solutions (NBSs) are attracting attention to reduce risks, to improve biodiversity and to develop ecosystemic services [3]. NBSs are increasingly studied as an alternative solution to reduce disaster risk triggered by hydro meteorological events [4]. Nevertheless, NBS is a recent terminology and is linked to other concepts such as, e.g., ecosystem-based adaptation (EbA), green infrastructure, and ecosystem-based approaches to disaster risk reduction [5-9]. The European Commission promotes ecosystem-based approaches and NBSs as they contribute to disaster risk reduction in line with the Sendai Framework for Disaster Risk Reduction 2015-2030, and also contribute to achieve other objectives, such as biodiversity conservation or climate change adaptation [5].

To allow widespread and effective implementation of NBS, several gaps need to be filled. Indeed, if the potential of NBSs for disaster risk reduction is well recognized [5,10-13], there is still a need for an appropriate quantification of the positive effects of NBSs [14]. In addition, ecological and socio-economic dimensions of NBSs are complementary and need to be taken into account [12] while local stakeholder engagement to transdisciplinary, multi-stakeholder and participatory process is critical for success [15,16]. However, limited research exists on the cost-benefit analysis of NBSs implementation [17] and social benefits may only be achieved a long time after the measure implementation [15]. 
In order to collect experience, there are many platforms and databases dedicated to NBSs or including NBSs [17]. They provide examples of possible measures, they contribute to knowledge-building, and make the outputs of research accessible to end-users [5]. Nevertheless, none of the existing platforms focuses on NBSs dedicated specifically to natural risks and environmental issues in hilly and mountainous areas. Thus, it makes it difficult for stakeholders to get a global view of possible NBSs applicable in mountainous areas, cases studies and performance evaluation. This is what motivated the realization of the PHUSICOS platform as many European countries have large mountainous areas and consequently are highly concerned.

\subsection{Objectives}

The PHUSICOS platform aims at gathering at the same place examples of NBSs applications and performance evaluation for NBSs used in hilly and mountainous areas.

The PHUSICOS database is innovative because:

- It focuses on NBSs dealing with hydro-meteorological triggered risks and environmental issues in hilly and mountainous areas (rural and urban),

- It provides an assessment of NBSs for up to 15 criteria.

This last point offers the opportunity for users to select good examples of NBSs relevant for their issue.

In addition, the PHUSICOS platform collects contributions from the community and this ensures that the database will continue to evolve and grow as NBSs are implemented and/or published online. To do so, interaction sessions will be organized within the frame of the H2020 PHUSICOS project during which stakeholders will be incited to contribute to the development of the platform by adding solutions.

This paper presents the PHUSICOS database structure and the NBSs platform review performed before the platform design. It also analyses the first PHUSICOS platform dataset, which identifies strong and weaker points of NBS application cases.

\section{Material and Methods}

The following method is a multi-steps approach (Figure 1). The first stage is to realize an inventory of existing and accessible NBS platforms. The analysis of the existing metadata within these platforms is used as a guide for the identification of the different items to be treated. A specification of the PHUSICOS platform is then realized followed by the creation and implementation of the prototype.

In parallel, the inventory of existing platforms is used to select all relevant NBSs for the PHUSICOS platform, i.e., NBSs applied for hydro-meteorological triggered hazards and environmental issues in mountainous and hilly areas. Once selected, these NBSs are recorded in the PHUSICOS database using the platform tools.

Finally, the inventory of existing platforms is used to determine the offered services. This list is used to define the ambits and criteria (based on the approach developped by Autuori et al. [18] to be applied for the assessment of each NBS stored within the PHUSICOS platform. These criteria are then applied to the records giving thematic information for the users and giving feedback on the current NBS practices for fighting hydro-meteorological hazards and risks in mountainous lands. Each step is detailed in the following chapters. 


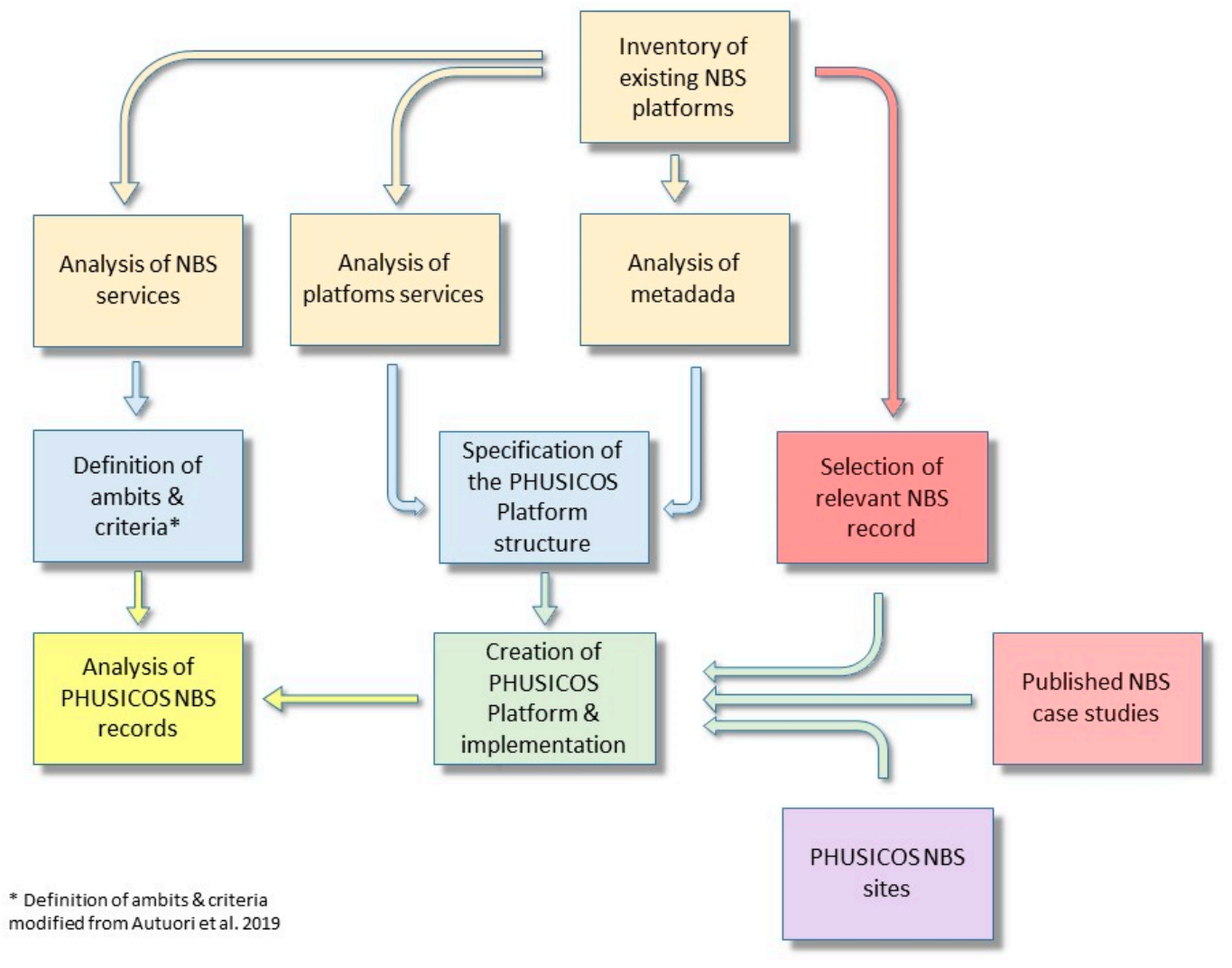

Figure 1. Method for construction of the PHUSICOS platform and database [18].

\subsection{Identification of Existing Platforms and Databases on NBSs}

They are many platforms dealing with nature-based solutions. Caroppi et al. [9] have inventoried almost 35 platforms with different objectives and services. For this work, we have focused only on the 11 platforms offering access to databases.

\subsubsection{Nature-Based Solutions Evidence Platform}

The Nature-based Solutions Evidence Platform is one of the two platforms proposed by the Nature-Based Solutions Initiative [19]. The overall objective of this platform is to "consolidate and facilitate access to the large, dispersed evidence-base on the effectiveness of NBSs for addressing climatic impacts on people and economic sectors, and thereby support global efforts to design and implement robust targets for nature in climate change and development policy". The tool proposes both empirical evidence and modelling/scenario evidence. Based on original articles, some evaluations of the cases based are displayed according to 3 criteria: effects on climate change impacts, social outcomes, and ecosystem outcomes. The platform gathers 203 scientific articles and 303 cases extracted from the articles.

\subsubsection{Natural Hazards-Nature-Based Solutions Platform}

The natural hazards-nature-based solutions platform [20] gathers example of "projects, investments, guidance and studies making use of nature to reduce the risks associated with natural hazards". The platform gathers 186 entries around the world. The platform also enables users to submit new projects for entry in the database.

\subsubsection{Oppla Platform}

Oppla [21] is an open platform which aims at responding to needs of different actors from science, policy and practice. Oppla offers three different services: (1) "Ask Oppla" is a crowd-sourced enquiry service. It is a forum where members of Oppla community can 
interact. (2) "Oppla Marketplace" is a knowledge database gathering all kind of useful resources (consultancy, dataset, document, event, guidance, software, and training), and it is also completed by a repository of case studies. (3) "Oppla community" is a networking system to interact with other members around the world, it is accessible to everyone. The Oppla platform gathers 292 case studies around the world with cases on 4 continents: Europe, Asia, Africa, and America.

\subsubsection{ThinkNature Platform}

The ThinkNature platform [22] allows online dialogue, knowledge repository, and networking. It gathers NBS Projects, Sites \& Platforms, a knowledge repository, a Hub for online resources on NBS state-of-the-art practise, Bucharest and Paris Forums, interviews, summer school, and webinars. In addition, ThinkNature provides other tools such as a game to play for simulating the role of the mayor of a city facing different challenges to be addressed with NBSs; a questionnaire on barriers and drivers for the implementation of NBSs; webinars to attend on different topics related to NBSs.

\subsubsection{Geospatial Information Knowledge Platform}

The Geospatial Information Knowledge Platform [23] (H2020 OPERANDUM project) proposes a NBSs explorer (map or table view allow to browse 94 literature solutions) and also the related policies. A dedicated section "OAL" for open-air laboratories provides detailed information on OPERANDUM open-air laboratories activities. A tab of the main menu also links to a crowdsourcing module that gathers 302 cases.

\subsubsection{Climate-Adapt Platform}

The Climate-ADAPT [24] platform aims to help users to access and share data and information regarding: expected climate change in Europe; current and future vulnerability of regions and sectors; adaptation strategies and actions; adaptation case studies and potential adaptation options; tools that support adaptation planning. The platform includes a database that contains quality-checked information with adaptation options, case studies, guidance, indicators, information portals, organizations, publication and reports, research and knowledge projects and tools. The platform gathers 40 adaptation options, 103 case studies, and 932 publications and reports.

\subsubsection{Urban Nature Atlas}

Urban Nature Atlas [25] contains almost 1000 examples of Nature-Based Solutions from across 100 European cities. The Urban Nature Atlas is a product from the H2020 NATURVATION project. The project assesses what nature-based solutions can achieve in cities, examines how innovation is taking place, and works with communities and stakeholders to develop the knowledge and tools required to realize the potential of naturebased solutions for meeting urban sustainability goals.

\subsubsection{PreventionWeb Platform}

PreventionWeb [26] is a knowledge center managed by the UN Office for Disaster Risk Reduction (UNISDR). It gathers documents, publications and news. It is not dedicated to NBSs but include documents of interest.

\subsubsection{Adaptation Community Platform}

AdaptationCommunity [27] was developed for the interested public and adaptation experts to provide information on applying approaches, methods and tools that facilitate the planning and implementation of adaptation action. Furthermore, enhancing knowledge and sharing experience is the key to successful adaptation strategies. Therefore, this platform offers a wealth of information, webinars and trainings on eight key topics including EbA which is the sustainable use and conservation of ecosystems and biodiversity as 
part of an overall adaptation strategy. The AdaptationCommunity platform gathers 34 publications on $\mathrm{EbA}$. It also lists examples of potential $\mathrm{EbA}$ measures for different domains.

\subsubsection{Panorama Platform}

PANORAMA-Solutions for a Healthy Planet [28] is a partnership initiative to document and promote examples of inspiring, replicable solutions across a range of conservation and sustainable development topics, enabling cross-sectoral learning and inspiration. PANORAMA allows practitioners to share and reflect on their experiences, to increase recognition for successful work, and to learn with their peers how similar challenges have been addressed around the globe. Different thematic disciplines and communities contribute to PANORAMA. The web platform gathers 102 Ecosystem-based solutions.

\subsubsection{The Equator Initiative}

The Equator initiative [29] brings together the United Nations, governments, civil society, businesses, and grassroots organizations to recognize and advance local sustainable development solutions for people, nature and resilient communities. It aims to recognize the success of local and indigenous initiatives; create opportunities and platforms to share knowledge and good practice; inform policy to foster an enabling environment for local and indigenous community action, and develop the capacity of local and indigenous initiatives to scale-up their impact. The NBS database of Equator initiative gathers 721 solutions around the world and mainly in the Southern countries.

\subsection{NBS Content, Services and Metadata for These Platforms}

To design PHUSICOS platform and database, the 11 platforms previously cited have been analysed in detail. The platforms offer different kind of services and gather heterogeneous data (Table 1). Most platforms reviewed for this work rely on databases. These databases offer a bench of common features such as key word search, filter search, heat maps or map views. The filter searches propose a set of basic filters to search into the database of articles, projects and/or NBS cases depending on the database. Data may be directly hosted by the concerned platform, but most of the time, only partial information is hosted and the reader is redirected for full detail access.

The metadata set used is also very different from one database to another (Table 2). Some databases give many details concerning the NBSs referenced and some others made the choice to reduce the number of metadata and redirect reader to original hosting websites. 
Table 1. Extract of services proposed by the platforms, for full table please refer to Appendix A.

\begin{tabular}{|c|c|c|c|c|c|c|c|c|c|c|c|c|}
\hline & & $\begin{array}{c}\text { NBS } \\
\text { Evidence } \\
\text { Platform }\end{array}$ & $\begin{array}{l}\text { Natural- } \\
\text { Hazard } \\
\text { NBS }\end{array}$ & Oppla & ThinkNature & GeoKP & $\begin{array}{l}\text { Climate- } \\
\text { Adapt }\end{array}$ & $\begin{array}{l}\text { Urban } \\
\text { Nature } \\
\text { Atlas }\end{array}$ & $\begin{array}{l}\text { Prevention } \\
\text { Web }\end{array}$ & $\begin{array}{l}\text { Adaptation- } \\
\text { Community }\end{array}$ & Panorama & $\begin{array}{l}\text { Equatorian } \\
\text { itiative }\end{array}$ \\
\hline \multicolumn{2}{|c|}{ Key words search } & $x$ & $\mathrm{x}$ & $x$ & & & $x$ & $\mathrm{x}$ & $x$ & & $\mathrm{x}$ & $\mathrm{x}$ \\
\hline \multirow{6}{*}{ Filter search } & $\begin{array}{c}\text { Nature elements } \\
\text { (coasts, mountains, } \\
\text { etc.) } \\
\text { /ecosystems }\end{array}$ & & & & & & & & & & $\mathrm{x}$ & $\mathrm{x}$ \\
\hline & CC impact & $\mathrm{x}$ & & & & & $x$ & & & & & \\
\hline & $\begin{array}{l}\text { Effects of NBS on } \\
\mathrm{CCI} / \text { Risk } \\
\text { reduction benefits }\end{array}$ & $\mathrm{x}$ & $\mathrm{x}$ & & & & & & & & & \\
\hline & Hazard & & $x$ & & & $\mathrm{x}$ & & & $x$ & & & \\
\hline & Cost range & & US\$ & & & & & $€$ & & & & \\
\hline & $\begin{array}{l}\text { Citizen involved } \\
\text { in monitoring }\end{array}$ & & & & & & & $\mathrm{x}$ & & & & \\
\hline \multirow{2}{*}{ Display } & Heat map & $\mathrm{x}$ & & & & & & & $x$ & & $x$ & \\
\hline & Map view & $\mathrm{x}$ & $\mathrm{x}$ & $\mathrm{x}$ & $\mathrm{x}$ & $x$ & & $\mathrm{x}$ & & & & \\
\hline \multirow[b]{2}{*}{ Data } & NBS only & $\mathrm{x}$ & $x$ & $\mathrm{x}$ & $\mathrm{x}$ & $x$ & & $\mathrm{x}$ & & & $x$ & \\
\hline & $\begin{array}{l}\text { Number of } \\
\text { case studies }\end{array}$ & 303 & 186 & 292 & 112 & 94 & 106 & 1000 & & & 134 & 721 \\
\hline \multirow{2}{*}{$\begin{array}{l}\text { Sources } \\
\text { of data }\end{array}$} & Articles & $x$ & & & & $x$ & $x$ & & & & & \\
\hline & Projects & & $\mathrm{x}$ & $\mathrm{x}$ & $x$ & $x$ & $x$ & $x$ & & & & $x$ \\
\hline \multicolumn{2}{|c|}{$\begin{array}{l}\text { Submit an entry } \\
\text { and/or crowdsourcing }\end{array}$} & & $\mathrm{x}$ & & & $\mathrm{x}$ & & & & & $x$ & \\
\hline
\end{tabular}


Table 2. Extract of metadata used in the different databases. The complete table is available in Appendix B.

\begin{tabular}{|c|c|c|c|c|c|c|c|c|c|c|c|}
\hline & & $\begin{array}{c}\text { NBS } \\
\text { Evidence } \\
\text { Platform }\end{array}$ & $\begin{array}{c}\text { Natural- } \\
\text { Hazard } \\
\text { NBS }\end{array}$ & Oppla & ThinkNature & GeoKP & $\begin{array}{l}\text { Climate- } \\
\text { Adapt }\end{array}$ & $\begin{array}{c}\text { Urban } \\
\text { Nature } \\
\text { Atlas }\end{array}$ & $\begin{array}{l}\text { Prevention } \\
\text { Web }\end{array}$ & Panorama & $\begin{array}{l}\text { Equatorian } \\
\text { itiative }\end{array}$ \\
\hline \multirow{4}{*}{ Description } & Title & $\mathrm{x}$ & $\mathrm{x}$ & $\mathrm{x}$ & $\mathrm{x}$ & $\mathrm{x}$ & $\mathrm{x}$ & $\mathrm{x}$ & $\mathrm{x}$ & $\mathrm{x}$ & $\mathrm{x}$ \\
\hline & Summary & $\mathrm{x}$ & $\mathrm{x}$ & & $x$ & & & $\mathrm{x}$ & & $\mathrm{x}$ & $\mathrm{x}$ \\
\hline & Objectives & & & $\mathrm{x}$ & $\mathrm{x}$ & $x$ & & & & & \\
\hline & Implementation activities & & & & $x$ & $\mathrm{x}$ & & $x$ & & & \\
\hline \multirow[b]{2}{*}{ Dates } & Date of publication/last edition & & & $\mathrm{x}$ & & & $\mathrm{x}$ & & & $\mathrm{x}$ & \\
\hline & $\begin{array}{c}\text { Project duration/ } \\
\text { Implementation time/Life time }\end{array}$ & & & & & & $\mathrm{x}$ & $\mathrm{x}$ & & & $\mathrm{x}$ \\
\hline Location & $\begin{array}{l}\text { Location (coordinates } \\
\text { and/or description) }\end{array}$ & & & $\mathrm{x}$ & $\mathrm{x}$ & $\mathrm{x}$ & & $\mathrm{x}$ & & $\mathrm{x}$ & $\mathrm{x}$ \\
\hline \multirow{2}{*}{ Domain } & $\begin{array}{l}\text { Intervention (habitat created, } \\
\text { restauration, combination) }\end{array}$ & $\mathrm{x}$ & $\mathrm{x}$ & & & $\mathrm{x}$ & & & & & \\
\hline & $\begin{array}{l}\text { Hazard addressed/ } \\
\text { Climate impacts }\end{array}$ & $x$ & $\mathrm{x}$ & & & $x$ & $\mathrm{x}$ & & & $\mathrm{x}$ & \\
\hline \multirow{7}{*}{ Evaluation } & Effects of NBS/NBS benefits & $x$ & & & $x$ & & & & & & \\
\hline & Risk reduction benefits & & $\mathrm{x}$ & & & & & & & & \\
\hline & $\begin{array}{c}\text { Impacts (on environment, } \\
\text { sustainable developments, ... ) }\end{array}$ & & & & $\mathrm{x}$ & & & $\mathrm{x}$ & & $\mathrm{x}$ & $x$ \\
\hline & Contributors (+ roles) & & & $x$ & $\mathrm{x}$ & & & $x$ & & $\mathrm{x}$ & \\
\hline & Sources/References & $x$ & & $x$ & $x$ & & $x$ & $\mathrm{x}$ & $x$ & & \\
\hline & Links & $\mathrm{x}$ & $\mathrm{x}$ & $x$ & $x$ & $\mathrm{x}$ & $\mathrm{x}$ & $\mathrm{x}$ & & $\mathrm{x}$ & \\
\hline & Organisation involved & & & $x$ & $x$ & & & & & $\mathrm{x}$ & $\mathrm{x}$ \\
\hline Finance & Project cost (and benefits) & & $\mathrm{x}$ & & & & $x$ & $\mathrm{x}$ & & & \\
\hline \multirow{2}{*}{ Participation } & Participatory approaches & & & & & & & $\mathrm{x}$ & & & \\
\hline & Community involvement & & & & & & $x$ & & & & \\
\hline
\end{tabular}




\subsection{Relevant NBSs Selection}

To select NBSs cases for the PHUSICOS database, existing databases content has been filtered with key words such as afforestation, mountain, flood, landslide, mudslide, rock fall, soil erosion, montane/alpine or avalanche. Thus, NBSs concerning natural risks and ecosystem services in hilly and mountainous areas (landslides, floods ... ) have been extracted. In addition, a literature review has been done in order to find others NBS cases study not referenced in platforms and databases [11,30-45].

In addition to this first set of measures, partners of the PHUSICOS project and stakeholders in charge of site where NBSs are applied have contributed (and will continue) to complete the database during events organized within the frame of PHUSICOS Living Labs. A significant contribution from partners has already been integrated especially for the Bavaria region, Germany.

\subsection{Comparative Assessment of the Solutions}

\subsubsection{The Criteria}

A comprehensive framework for the assessment of NBSs in context of natural hazard risk mitigation and ecosystem services monitoring has been designed $[9,18]$. This framework will be used to assess the NBSs implemented at demonstrator sites, but it is not adapted to evaluate NBSs collected through databases and literature review due to the lack of detailed data. In consequence, the detailed assessment framework developed by Autuori et al. [18] is composed by nested levels of descriptors. For the PHUSICOS platform, the frame has been simplified and adapted. We consider that the second level of the framework ("Criteria") does not require too detailed data while being sufficiently informative for our analysis (Table 3).

Table 3. Purpose and resulting ambits and criteria adapted from Autuori et al. [18].

\begin{tabular}{|c|c|c|}
\hline Purpose & Ambit & Criteria \\
\hline \multirow{3}{*}{$\begin{array}{l}\text { Verify NBSs performances and their } \\
\text { effectiveness with respect to risk reduction; }\end{array}$} & \multirow{3}{*}{ Risk reduction } & Hazard \\
\hline & & Exposure \\
\hline & & Vulnerability \\
\hline \multirow{2}{*}{$\begin{array}{l}\text { Assess the technical and economic } \\
\text { feasibility aspects }\end{array}$} & \multirow{2}{*}{ Technical \& economic feasibility } & Technical feasibility \\
\hline & & Economic feasibility (affordability) \\
\hline \multirow{5}{*}{$\begin{array}{l}\text { Assess the beneficial role of NBSs on } \\
\text { the environment }\end{array}$} & \multirow{5}{*}{ Environment } & Water \\
\hline & & Soil \\
\hline & & Vegetation \\
\hline & & Landscape (green infrastructure) \\
\hline & & Biodiversity \\
\hline \multirow{3}{*}{$\begin{array}{l}\text { Identify positive co-benefits and potentially } \\
\text { undesirable side-effects from the societal point } \\
\text { of view }\end{array}$} & \multirow{3}{*}{ Society } & Quality of life \\
\hline & & Community involvement and governance \\
\hline & & Landscape and heritage \\
\hline \multirow{2}{*}{$\begin{array}{l}\text { Assess the effects of the NBSs on the } \\
\text { local economy }\end{array}$} & \multirow{2}{*}{ Local economy } & Revitalization of marginal areas \\
\hline & & Local economy reinforcement \\
\hline
\end{tabular}

\subsubsection{Qualification of Criteria}

The simplified approach aims to assess qualitatively the effect of the selected NBS at the criteria level thanks to explicit assessment available in the original study. The idea is not to perform an expert judgement for all criteria but rather to rely on the existing assessments performed during the implementation of the NBS at the sites as it is proposed 
by the Nature Based Initiative on their platform for three criteria (effects of NBS, ecological outcomes and social outcomes).

The criteria level is sufficiently general to be analysed for the entire PHUSICOS platform NBSs whatever the type of work, the realized approaches, the problematic or the spatial or temporal scale. Moreover, a unique metric cannot be assigned at the level of the criteria, but a qualitative analysis of the result obtained for each criterion can be realized. It is a matter of giving a qualitative value of the incidence of the NBS on each criterion:

- " + " if the NBS have a positive impact on the criterion,

- " " " if the NBS have a negative impact on the criterion,

- " + / - " if the NBS have an ambiguous impact either in function of the case at which it is applied or in function of the effect on the sub-criterion (positive for one but negative for another),

- " "0" if the NBS have no impact,

- "?" if the impact is unclear or unknown,

- "NA" when the criterion assessment is not applicable or irrelevant.

Once all criteria of all NBSs are assigned, it is possible to sort the NBSs in function of the assessment of one or multiple criteria. This classification was used by Baills et al. [46] and is very similar and coherent with categories used by the University of Oxford for their Nature Based Initiative. The main difference is that the PHUSICOS platform uses six categories when the Nature Based Initiative uses five (Table 4). Indeed, this last one defines the unclear category as "when the authors do not derive an explicit conclusion as to whether the NBS intervention has either negative, positive, or neutral outcomes as per the above definitions", which corresponds to the "?" category in PHUSICOS classification, but it doesn't have any category for "neutral" outcomes (i.e., the NBS as no effect on the criterion).

Table 4. Comparison between Oxford classification (https:/ / www.naturebasedsolutionsevidence. info/) and the PHUSICOS platform classification.

\begin{tabular}{cc}
\hline Oxford Classification & PHUSICOS Classification \\
\hline Positive & + \\
\hline Negative & + \\
\hline Mixed & 0 \\
\hline Unclear & $?$ \\
\hline Not applicable & NA
\end{tabular}

This assessment allows refining the search among NBSs and to list good examples of NBSs regarding to stakeholders' priorities. Indeed, a stakeholder can identify its priority criteria (for example "soil", "water", and "quality of life") and select NBSs that score "+" for these criteria. It can also be used to identify the NBSs that fulfil positively the higher number of criteria.

A multi-criteria analysis carried out on the basis of the evaluation of each criterion would not make sense because it would lead to deal with NBSs of different natures and applied to specific local contexts (morphological, climatic, biological, etc.).

\section{Results}

\subsection{PHUSICOS Database Structuration and Useful Descriptors}

The structure of the PHUSICOS database is based on the analysis of the 11 platforms previously mentioned. Thirty-nine metadata fields have been selected and divided into height categories (Table 5) and for 15 of those 39 fields, closed lists of possible answers are proposed. These lists are detailed in Appendix C. 
Table 5. List of fields used by the PHUSICOS database.

\begin{tabular}{|c|c|c|}
\hline Categories & Fields & Closed List of Answers \\
\hline \multirow{7}{*}{ Description of the solution } & Summary & \\
\hline & Technical characteristics & \\
\hline & Success factors/lessons learnt & \\
\hline & Limiting factors/lessons learnt & \\
\hline & Longitude & \\
\hline & Latitude & \\
\hline & Comment on location & \\
\hline \multirow{4}{*}{ Keywords } & Ecosystems impacted & Yes \\
\hline & Hazards concerned & Yes \\
\hline & Others challenges & Yes \\
\hline & Other keywords & \\
\hline \multirow{2}{*}{ Exposition } & Assets exposed & Yes \\
\hline & Population exposed & Yes \\
\hline \multirow{4}{*}{ Activity } & Job created in NBS sector & Yes \\
\hline & New employments in tourism sector & Yes \\
\hline & New activities in tourism sectors, sport or recreational activities & Yes \\
\hline & New/traditional activities increase & Yes \\
\hline \multirow{2}{*}{ International classification } & Sustainable development goals addressed & Yes \\
\hline & Sendai Framework priorities addressed & Yes \\
\hline \multirow{3}{*}{ Actors } & Beneficiaries of the actions & \\
\hline & Contact person & \\
\hline & Organizations involved in the implementation & \\
\hline \multirow{2}{*}{ Temporal aspects } & Design life time of the action & Yes \\
\hline & Implementation time of the action & Yes \\
\hline \multirow{7}{*}{ Financial aspects } & Action costs & \\
\hline & Avoided costs/added value for co-benefits & \\
\hline & Maintenance costs & \\
\hline & Replacement costs & \\
\hline & Payback period & \\
\hline & Financing source & \\
\hline & Comment & \\
\hline \multirow{8}{*}{ Others } & Participatory process & Yes \\
\hline & Participatory approaches/community involvement & \\
\hline & Possibility to transpose in a different context & Yes \\
\hline & Pictures & \\
\hline & Videos & \\
\hline & Links & \\
\hline & References & \\
\hline & Other comment & \\
\hline
\end{tabular}




\subsection{PHUSICOS Platform Characteristics}

\subsubsection{Design of the Tool}

PHUSICOS platform proposes three interfaces to explore the dataset. In addition to these interfaces, an information tab gathers documents of interest concerning NBSs and adding a new solution is possible thanks to questionnaire form. Finally, the "solution page" gives access to all available metadata and also to the evaluation restitution for the chosen solution.

- The three data interfaces

\section{Database interface}

Three different interfaces allow browsing the data. The first interface is a database interface (Figure 2), which allows classic browsing with or without filters. It is also on this page that the "Add a solution" form can be accessed.

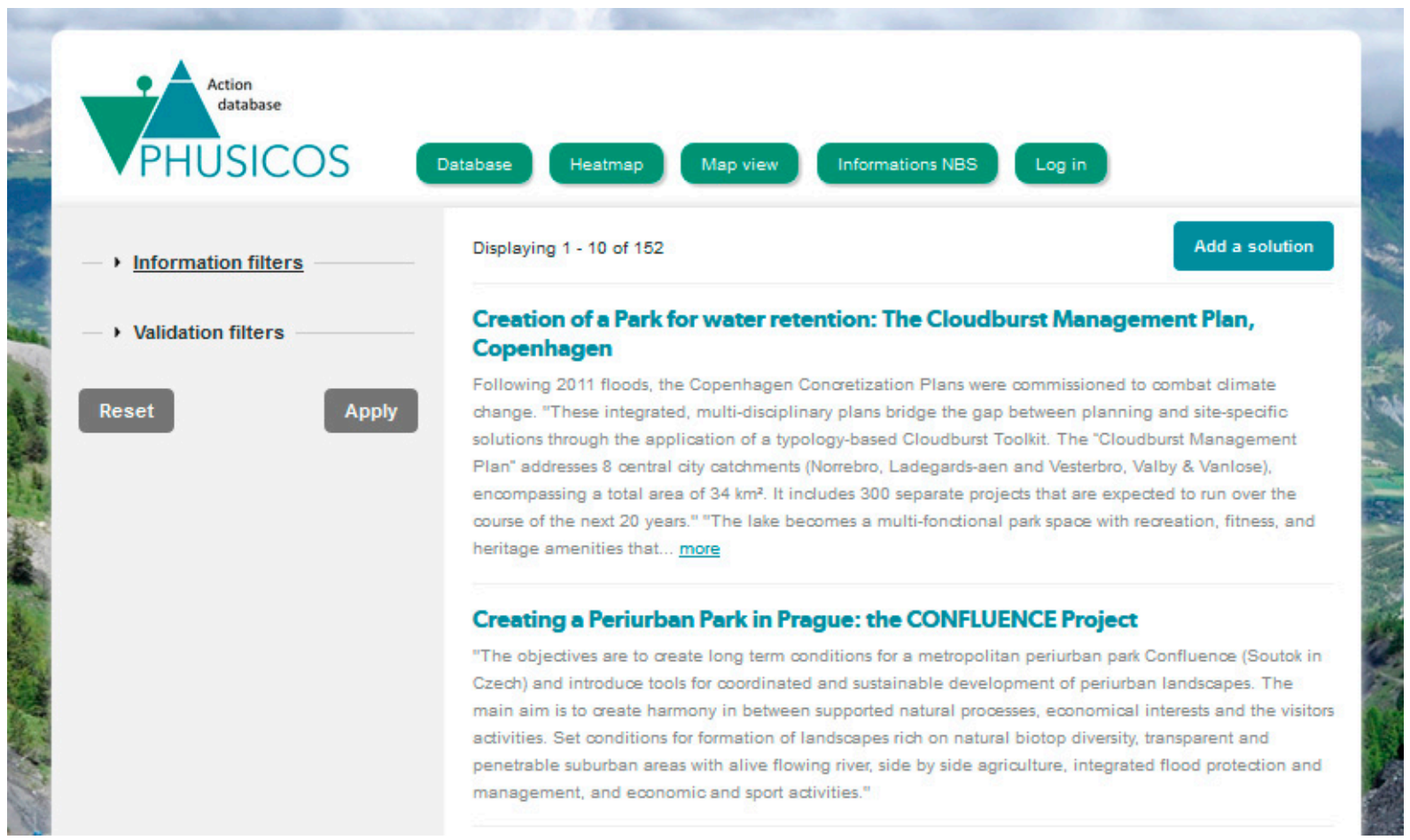

Figure 2. PHUSICOS database and home page. The "Add a solution" button (top right) allows to access the form to propose new entries.

\section{Map view}

The map view (Figure 3) offers an overview of geographical repartition of NBSs cases. In addition, GIS data layers at higher resolution will be added in the future for some major case studies and in order to have a better spatial representation at detailed scale. Similarly, the data will be displayed when zooming on the case study location. 


\section{PHUSICOS Database Heatmap Map view Informations NBS}

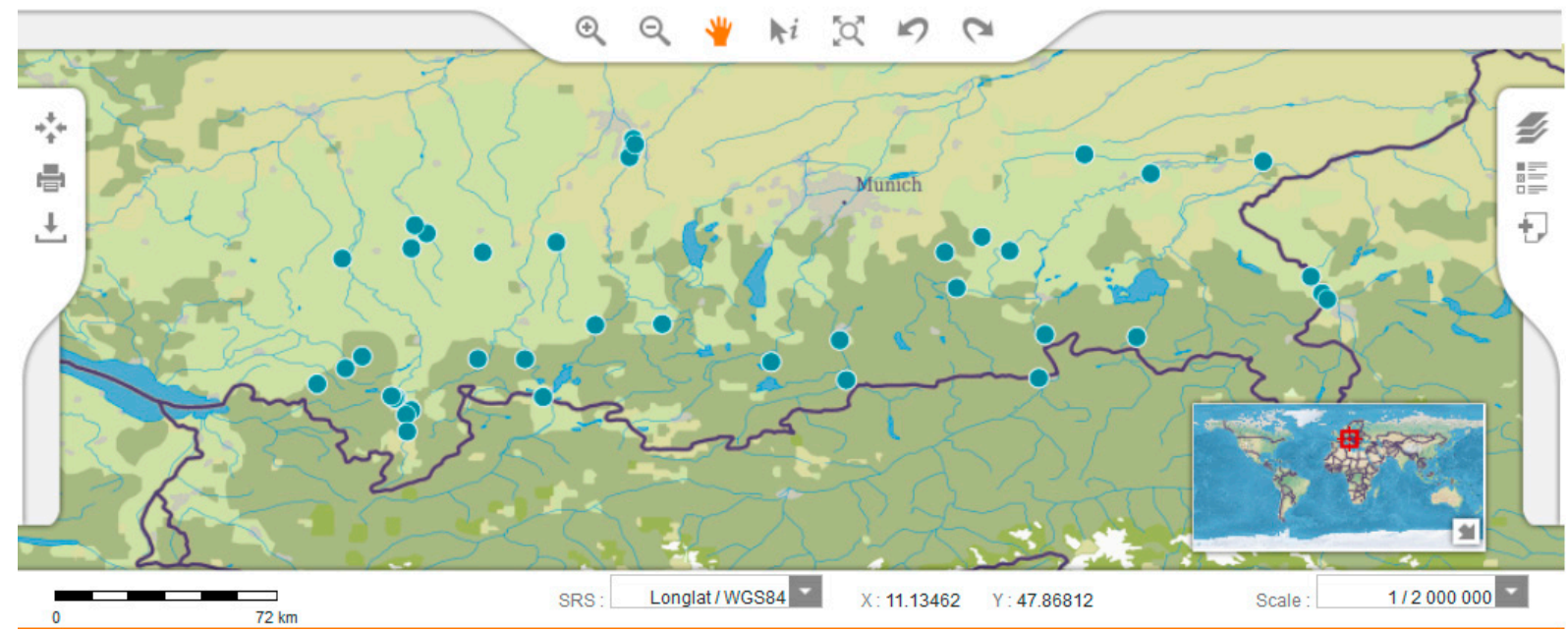

Figure 3. Example of PHUSICOS platform map view.

\section{Heat map}

A heat map (Figure 4) allows different and in depth browsing of data. Currently, five fields are available for the heat map ("hazard concerned", "ecosystem impacted", "assets exposed", "other challenges", and "Sustainable Development Goals addressed").

\section{Heatmap}

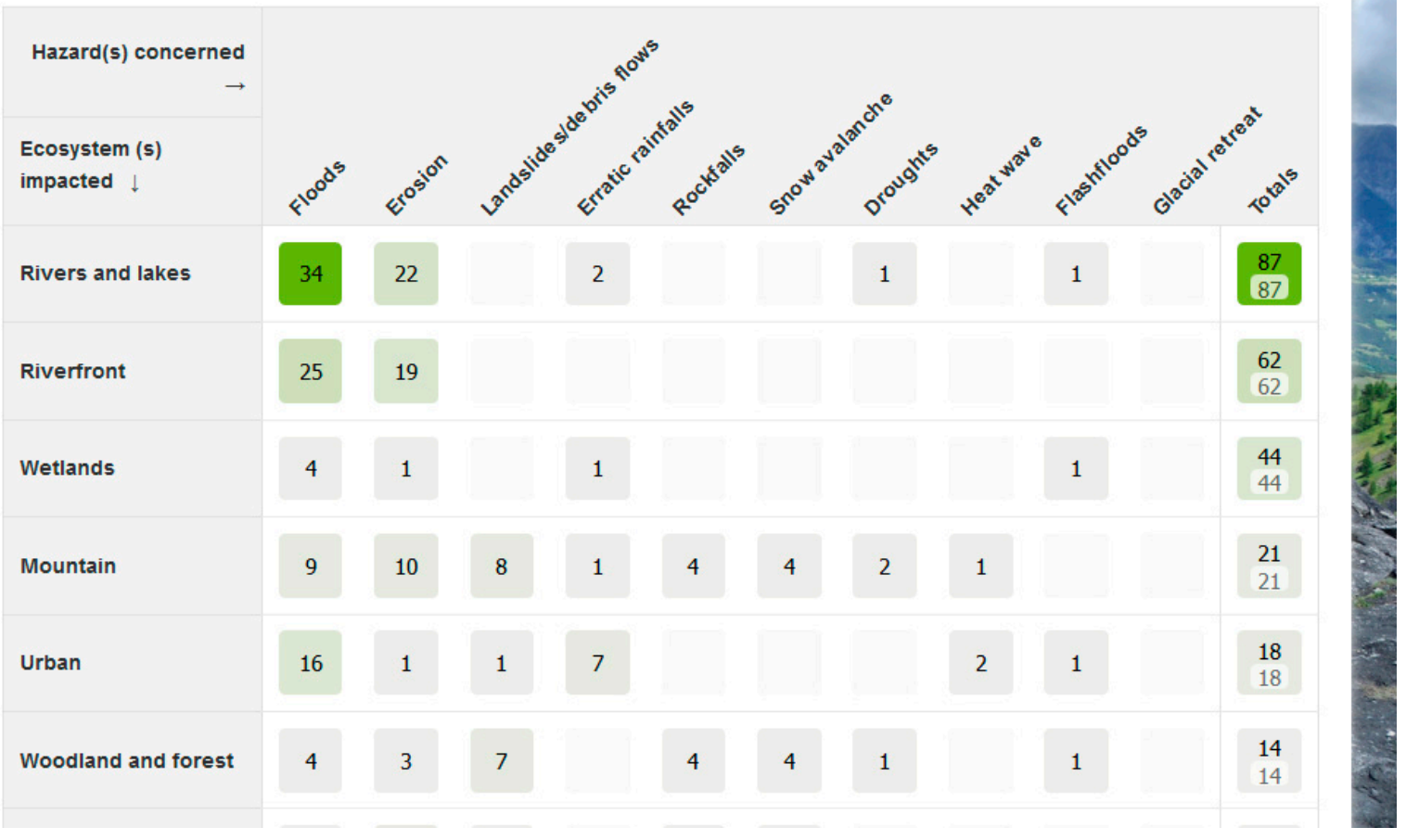

Figure 4. Example of heat map view.

- Solution detailed page 
The three interfaces presented previously allow accessing directly to the solution detailed page, which gather two tabs. The first one, entitled "Information" presents all available metadata and the second one, "Evaluation" presents the evaluation graphical restitution. For the restitution of the qualitative assessment, pictograms (Figure 5) and colour codes ("green" for positive impact, "orange" for mixed impact, "red" for negative impact, "blue" for neutral and "grey" for unclear or unknown) are used to offer a quick overview of the results. In addition, help pop-up are available with criteria definitions and colour legends (Figure 6). Examples of both tab views are presented in Figures 7 and 8.

\begin{tabular}{|c|c|c|}
\hline Ambit & Criterion & Symbol \\
\hline \multirow{3}{*}{$\begin{array}{l}\text { Risk } \\
\text { reduction }\end{array}$} & Hazard & \\
\hline & Exposure & \\
\hline & Vulnerability & \\
\hline \multirow{2}{*}{$\begin{array}{c}\text { Technical \& } \\
\text { economic } \\
\text { feasibility }\end{array}$} & $\begin{array}{l}\text { Technical } \\
\text { feasibility }\end{array}$ & \\
\hline & $\begin{array}{l}\text { Economic } \\
\text { feasibility }\end{array}$ & \\
\hline \multirow{5}{*}{ Environment } & Water & \\
\hline & Soil & \\
\hline & Vegetation & \\
\hline & Landscape & \\
\hline & Biodiversity & \\
\hline
\end{tabular}

\begin{tabular}{|c|c|c|}
\hline Ambit & Criterion & Symbol \\
\hline \multirow{4}{*}{ Society } & $\begin{array}{c}\text { Community } \\
\text { involvement }\end{array}$ & $\begin{array}{c}\text { Quality of life } \\
\text { Landscape } \\
\text { and heritage }\end{array}$ \\
\cline { 2 - 3 } & $\begin{array}{c}\text { Revitalization } \\
\text { of marginal } \\
\text { areas }\end{array}$ \\
\hline \multirow{2}{*}{ Local } & $\begin{array}{c}\text { Local } \\
\text { economy } \\
\text { reinforcement }\end{array}$ \\
\hline
\end{tabular}

Figure 5. List of symbols used and correspondence with criteria and ambits. 


\section{Hazard}

Definition of assessment values for the hazard criterion

\begin{tabular}{|c|c|c|c|}
\hline Hazard & Value & Symbol & Signification \\
\hline \multirow{6}{*}{$\begin{array}{l}\text { Whatever the type of hazard concerned within the } \\
\text { PHUSICOS project (flood, debris flows, landslides...), this } \\
\text { assessment focus on the effect of NBS on the Hazard level }\end{array}$} & + & & $\begin{array}{l}\text { The NBS and correlative actions reduce the hazard level i.e. lowering the } \\
\text { water height or current velocity for flooding, stabilizing the landslide etc. }\end{array}$ \\
\hline & - & & $\begin{array}{l}\text { The NBS and correlative actions are negative in term of reduction of hazard } \\
\text { level i.e. increasing the hazard level }\end{array}$ \\
\hline & $+/-$ & & $\begin{array}{l}\text { The NBS and correlative actions are positive or negative in term of } \\
\text { reduction of hazard level depending on the context or specific locations, or } \\
\text { it is positive for one of the concerned hazards but negative for another }\end{array}$ \\
\hline & 0 & & $\begin{array}{l}\text { The NBS and correlative actions have no effect on the hazard level or the } \\
\text { magnitude of the effect is too tiny to be detected }\end{array}$ \\
\hline & $?$ & & $\begin{array}{l}\text { The effect of the NBS and correlative actions on the hazard level is } \\
\text { unknown }\end{array}$ \\
\hline & NA & NA & The criterion assessment is not applicable or irrelevant \\
\hline
\end{tabular}

Figure 6. Example of pop-up window for hazard criterion with the definition of the selected criterion and colour codes.

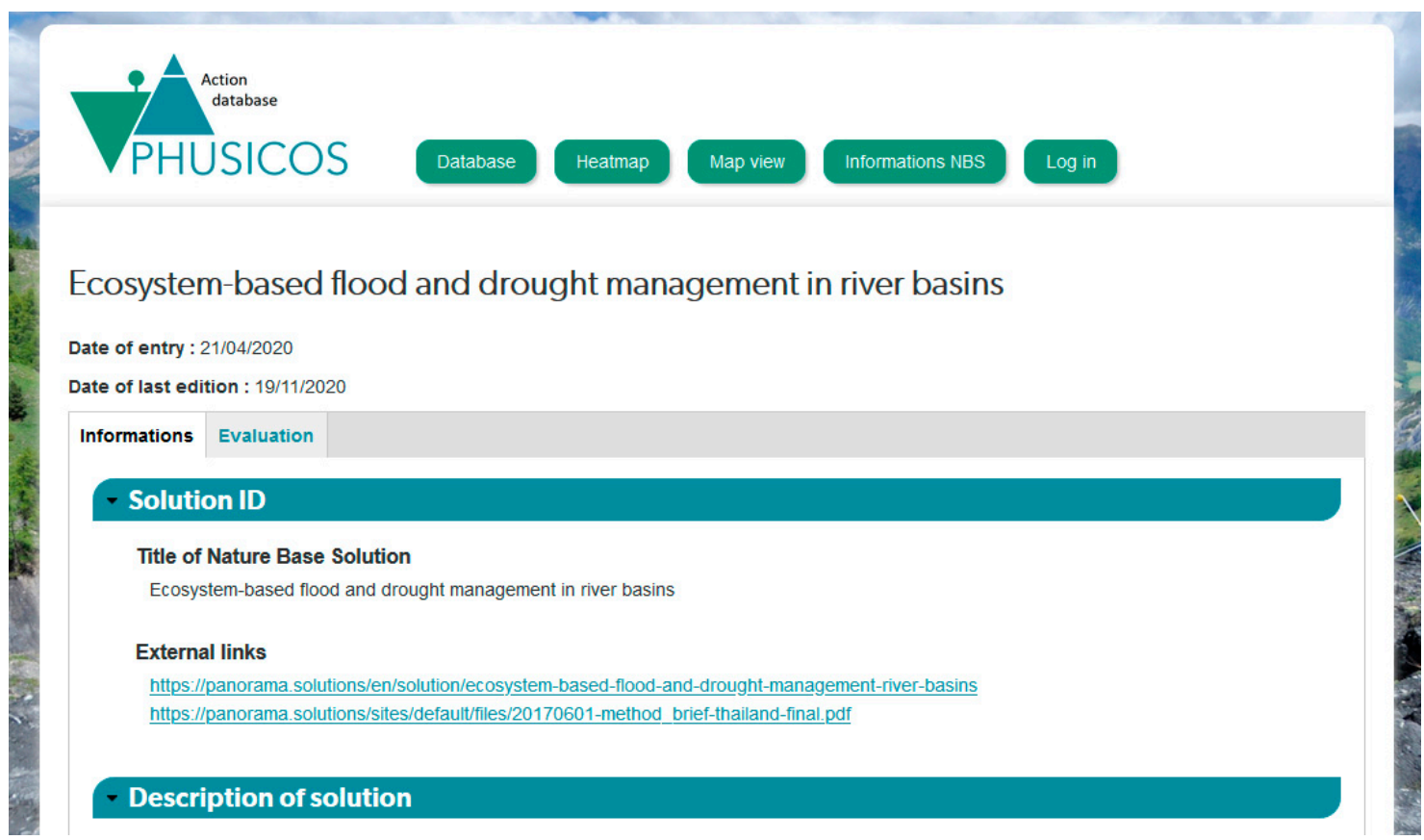

Figure 7. Solution detailed page, information tab. 


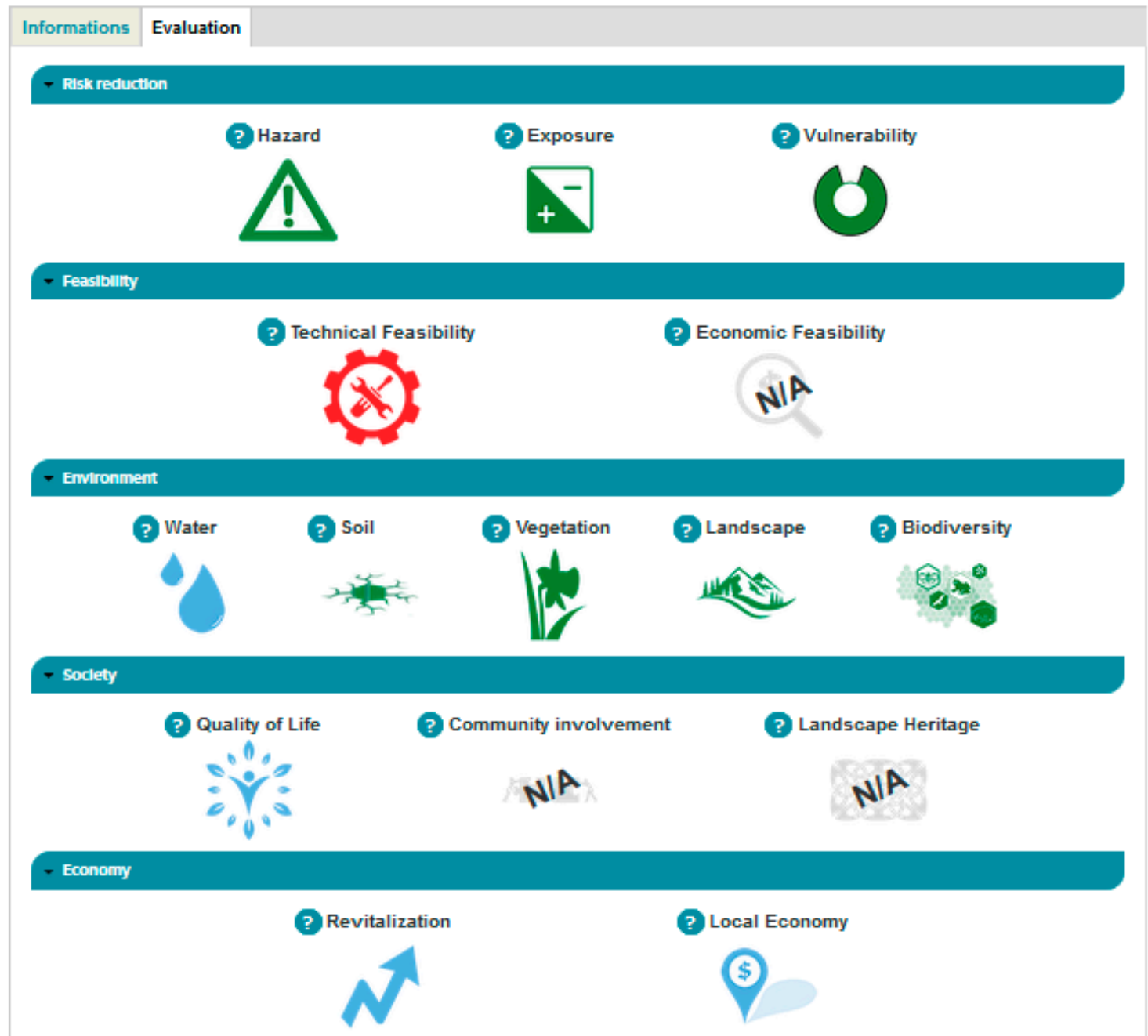

Figure 8. Example of the restitution page for the assessment of a NBS.

\subsubsection{Operating the PHUSICOS Platform}

The PHUSICOS platform is accessible directly through a web portal (http:/ / phusicos. brgm.fr) or via the project website (https:/ / phusicos.eu/). The portal is available in English. Read-only is accessible to everyone and an account is required only to contribute to enrich the database by submitting new solutions.

The database is based on an open-source content management system (CMS) website [47]. The system supports file storage for documents and a map server to provide geo-referenced access to the cases studies stored in the database.

\subsubsection{Personal Data}

The personal data concept covers all information related to an individual who is identified or who may be identified, directly or indirectly, in particular with reference to an identifier (for example, a name or identification number) or to one or more elements specific to their physical, physiological, genetic, mental, economic, cultural or social identity.

To this end, the PHUSICOS platform undertakes to respect Regulation (EU) 2016/679 of the European Parliament and Council of 27 April 2016 on the protection of natural persons with regards to the processing of personal data and the free movement of such data, and repealing Directive 95/46/EC, hereafter referred to as "GDPR", and the modified law $\mathrm{n}^{\circ}$ 78-17 of 6 January 1978 on IT, files and liberties, hereafter referred to as "the Regulation".

The policy that describes how we collect, use and manage personal data and the rights of the users concerned is available online at http://phusicos.brgm.fr/node/547. 
For any information about personal data protection, you may also consult the website of the French National IT and Liberties Commission.

\subsubsection{PHUSICOS Platform Scalability \& Sustainability}

The PHUSICOS platform will be maintained for at least five years after the end of the project (i.e., 2028). After this date, additional funding for maintenance will be search for and in addition, the content of the PHUSICOS platform will be transferred to "permanent" data repository such as BRGM institutional web site and/or Mendeley Data Repository to ensure durability of access to the content.

\subsection{Preliminary Analysis of the Entries}

The PHUSICOS database currently gathers 152 entries. The database will continuously be enriched by the addition of PHUSICOS demonstration sites data and also by the involvement of stakeholders who will be encouraged to feed the database with their experience.

To characterize and analyse the current 152 solutions, we have worked on the following four categories:

- The nature of impacted ecosystems,

- The hazard(s) concerned,

- The other challenges treated by the NBS,

- The type of exposed assets.

\subsubsection{Ecosystem Nature}

Nine types of impacted ecosystems are identified: "mountains", "rivers", "wetlands", "grasslands", "woodlands and forests", "croplands", "heathlands", "lakes", and "urban areas". This last one is a hybrid of natural and man-made elements interacting.

Figure 9 show that the dominant ecosystem targeted by the NBSs are "rivers" $(57.2 \%)$ followed by "wetlands" (28.9\%), "mountains" (13.8\%), and "urban areas" (11.8\%).

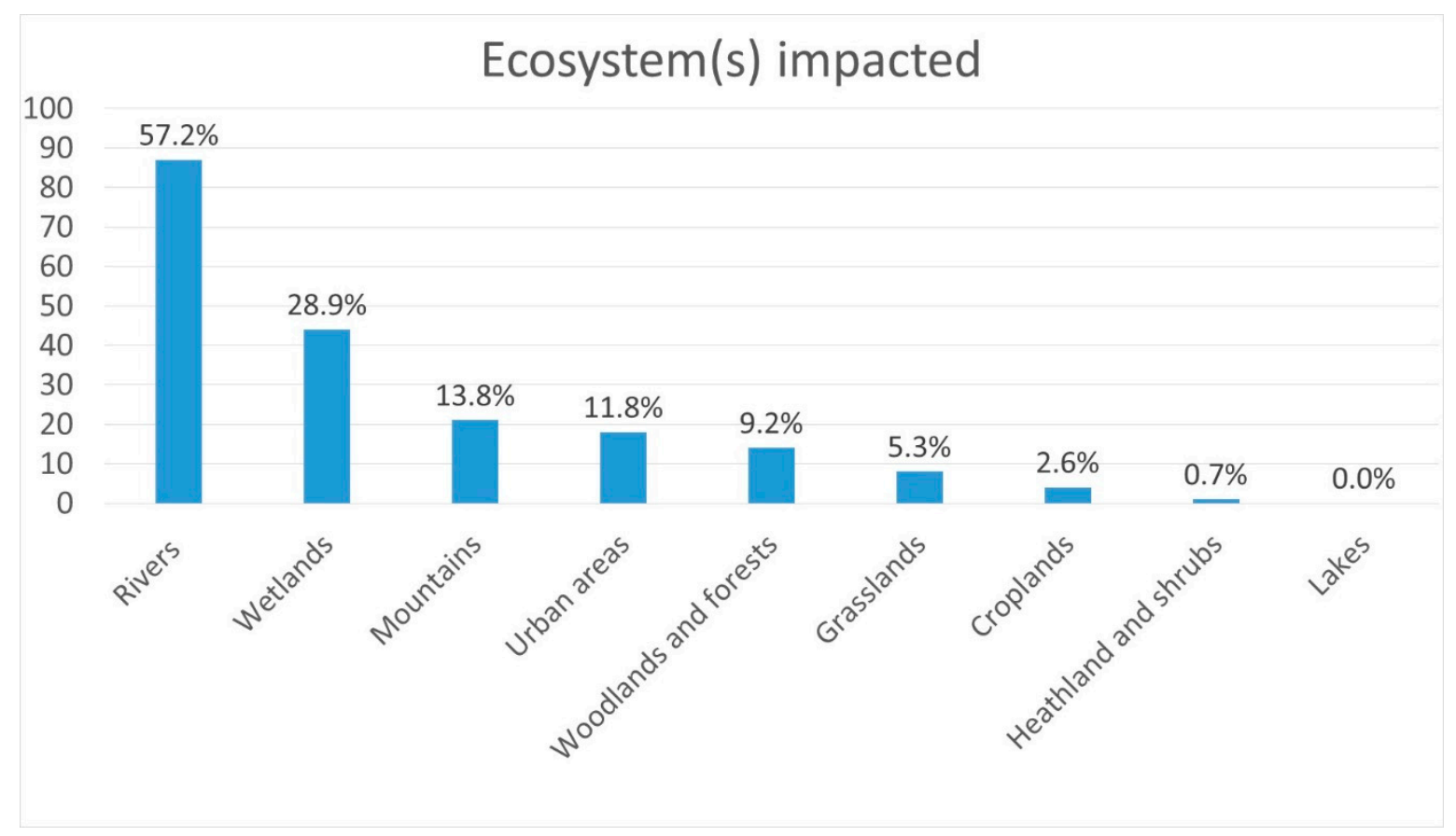

Figure 9. Number of NBSs by nature of impacted ecosystem. 


\subsubsection{Hazard Concerned}

Eight categories and subcategories of hazard are fight by the NBSs: "floods", "landslides", "rock falls", "snow avalanches", "erosion", "heat waves", "droughts", and "glacial retreat".

"Floods" are the largely dominant hazard treated by NBS (36.2\%) followed by "erosion" (17.1\%) while "landslides \& rock falls" recover together $8.5 \%$ of the cases (Figure 10). The other hazards represent only few percentage each ones.

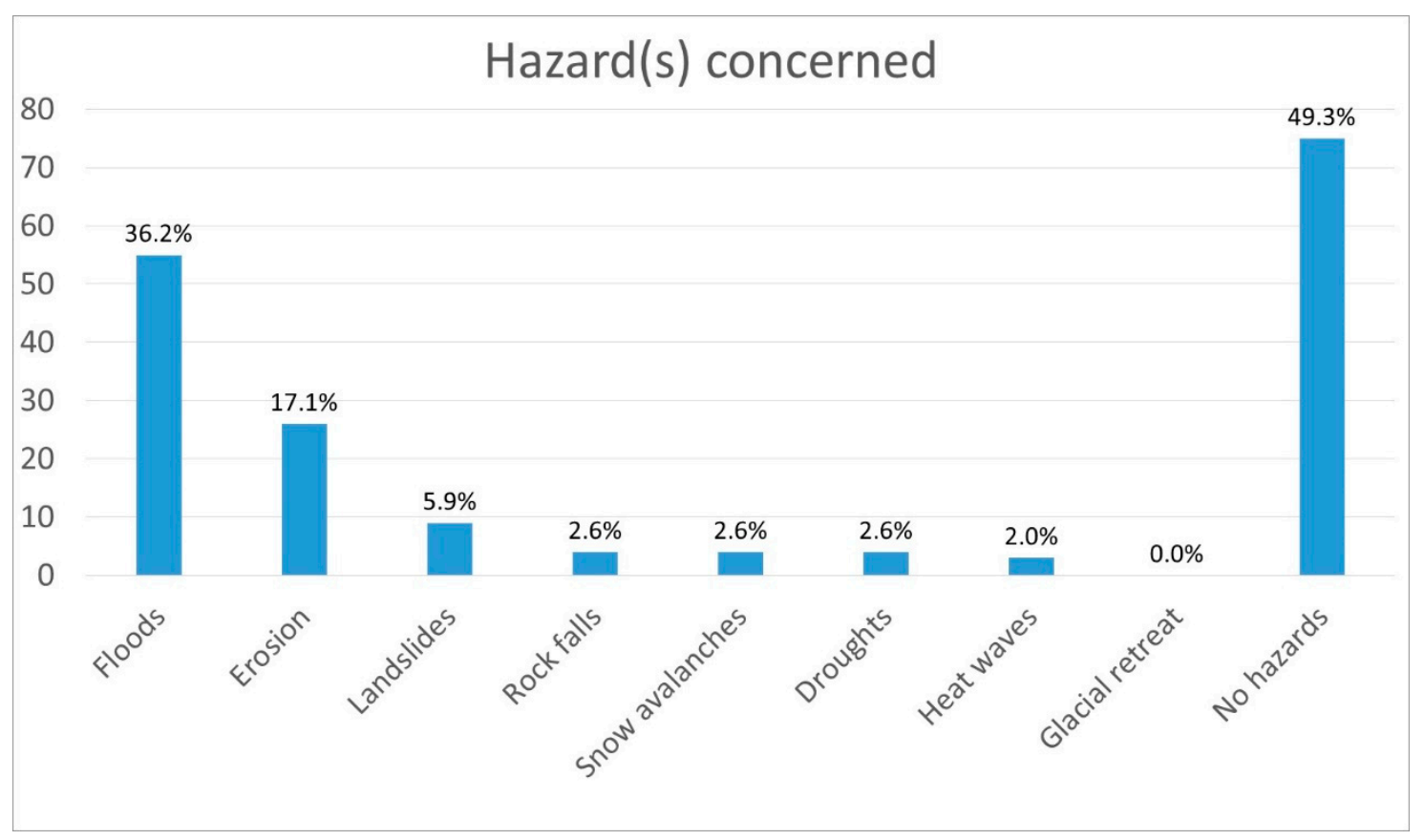

Figure 10. Number of NBS by hazard concerned.

There are many NBS cases which aren't tag with any hazards (49.3\%). The reason for this is that for almost half of the cases, the primary aim of the NBS implementation is devoted to biodiversity and ecosystem conservation or restoration in order to preserve or restore ecosystem services. Then, the risk reduction by the NBS is only a co-benefit.

\subsubsection{Others Challenges}

Thirteen other keywords aim at identifying other challenges in relation with the implementation of NBSs: "ecosystem conservation", "ecosystem restoration", "biodiversity", "climate adaptation", "landscape \& cultural heritage", "local community involvement", "human well-being \& recreational activities", "governance", "infrastructure", "financing", "science and research", "job creation", and "outreach \& communications".

Unsurprisingly, "biodiversity", "ecosystem conservation", and "ecosystem restoration" are challenges frequently addressed by NBS implementation $(82.2 \%, 58.6 \%$, and $12.5 \%$ ). "Human well-being" is mainly treated on a recreational perspective and is the frequent subject (15.8\%). "Climate adaptation" is explicitly treated by only $12.5 \%$ of the NBSs. (Figure 11). The "local community involvement" is clearly identified for only seven NBSs. 


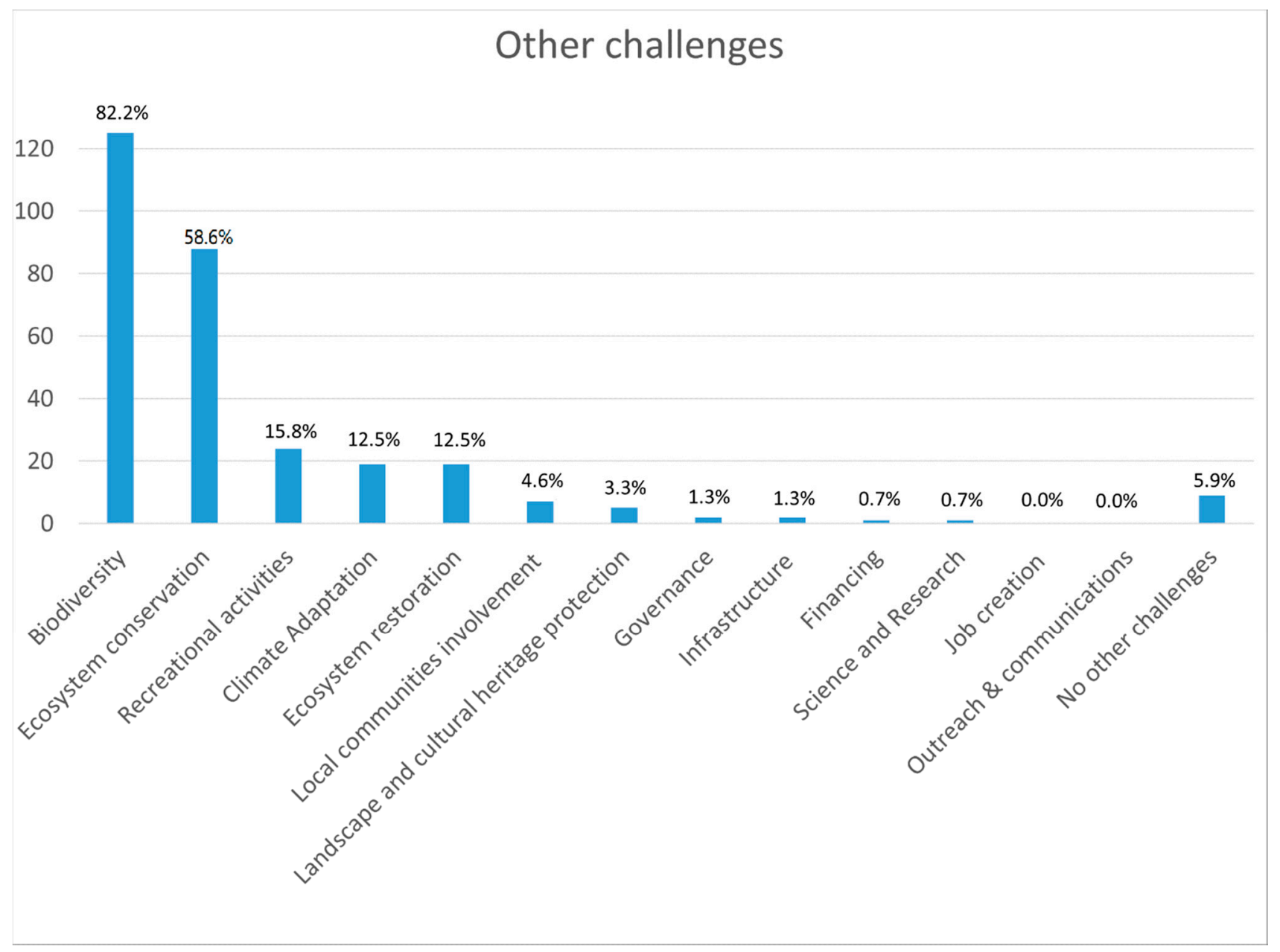

Figure 11. Number of NBS by other challenge.

\subsubsection{Type of Assets}

Seven types of exposed assets are identified: "urban (dense built area) or residential areas", "strategic buildings", "industrial buildings", "roads", "railways", "lifelines", and "agriculture".

Very little information is available for this field as it is empty for $18.4 \%$ of cases and $39.5 \%$ are answered unknown. "Urban or residential areas" are the most represented $(16.4 \%)$, closely followed by "agricultural assets" (15.8\%) (Figure 12).

The lack of information regarding the exposed assets is mainly due to the type of data included in the database. Indeed, the database currently gathers mostly literature cases and the source of data seldom provide information on the exposed assets. 


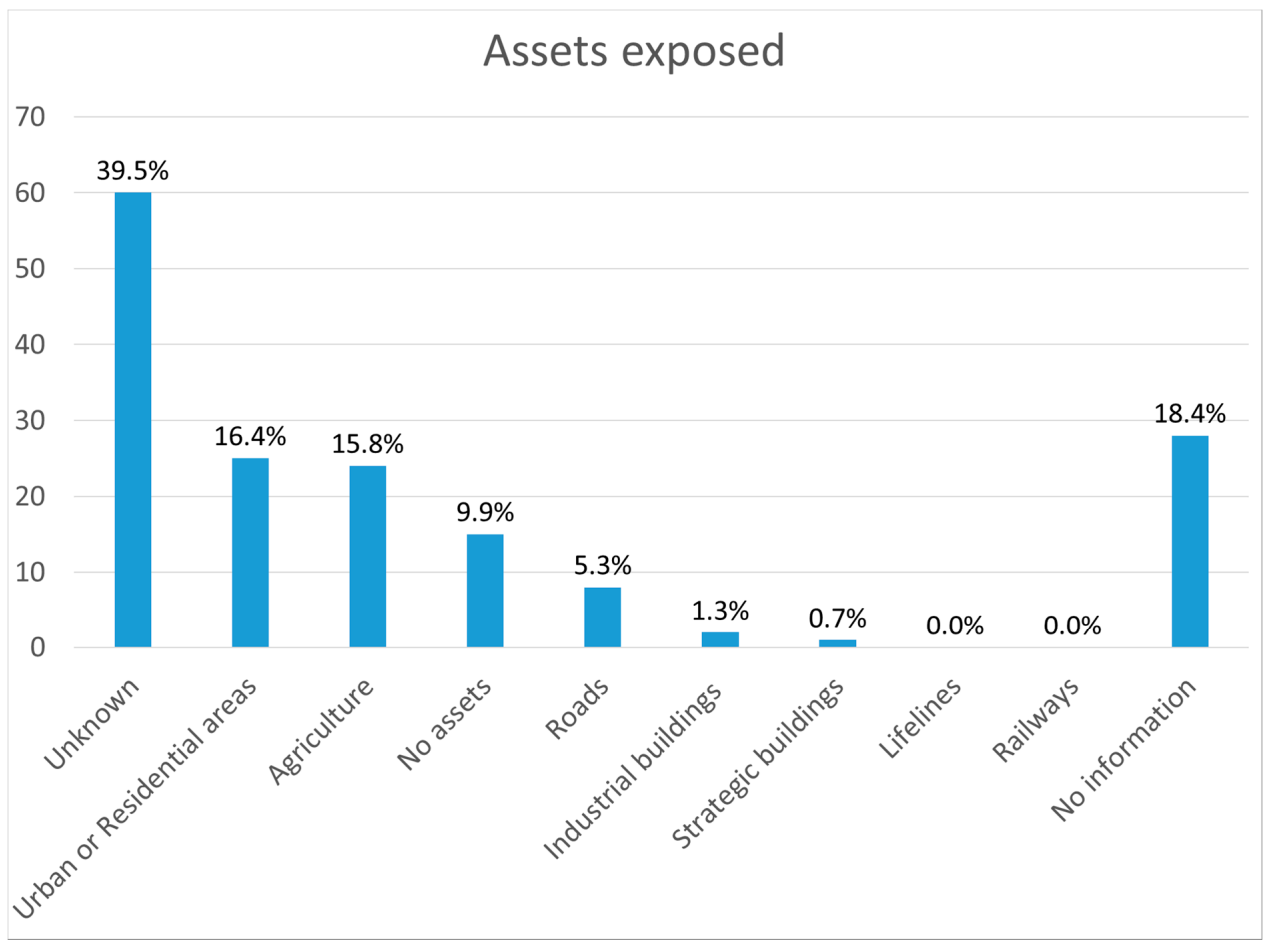

Figure 12. Number of NBS by type of exposed assets.

\subsubsection{NBS Assessment}

The PHUSICOS NBS assessment module has just become operational and, as previously stated, the database is intended to evolve. However, a first insight of NBSs' assessment was realized for the 15 criteria gathered by ambit.

Regarding "disaster risk reduction" ambit (Figure 13), at least half of the NBS cases from the PHUSICOS database are rated "?" as no information is available in the case study restitutions on the impact of those NBS for at least one of the three "disaster risk reduction" criteria. Nevertheless, 35\% of the NBSs analysed perform positively regarding "hazard" criterion against $25 \%$ for "exposure" criterion and $23 \%$ for "vulnerability" criterion.

Hazard

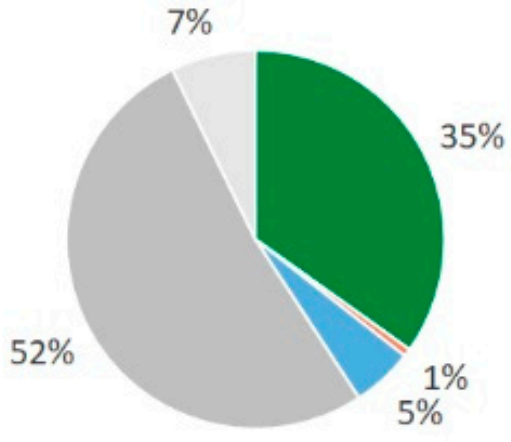

Exposure

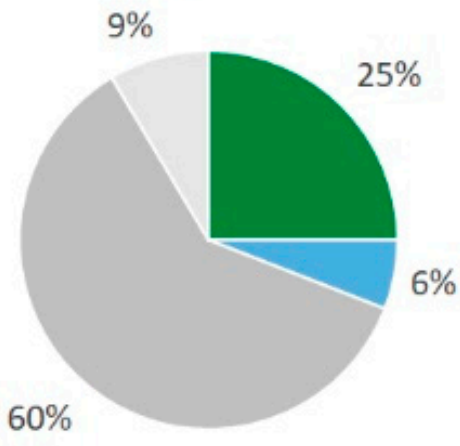

Vulnerability

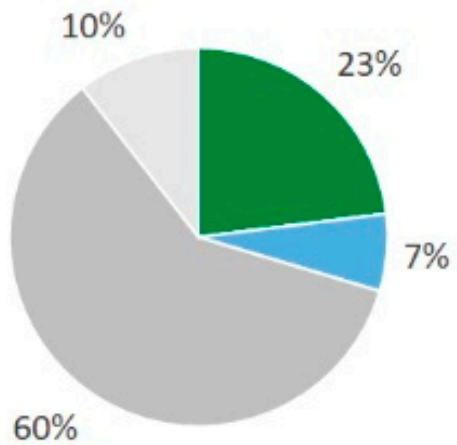

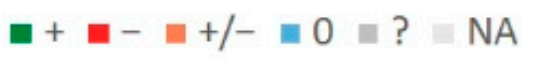

Figure 13. Repartition of evaluation categories for the criteria of the "disaster risk reduction" ambit.

No NBS have identified negative impacts on "disaster risk reduction criteria" and 1\% of the NBS have mixed impacts on hazard criterion.

Assessment of NBS regarding "technical \& economic feasibility" ambit (Figure 14) is almost the same for "technical feasibility" criterion and "economic feasibility" criterion. 
For $40 \%$ of the NBS both criteria are positively evaluated ( $41 \%$ for "technical feasibility" and $43 \%$ for "economic feasibility"), $30 \%$ have mixed "technical and economic feasibility", and $1 \%$ negative assessments.

\section{Technical feasibility}

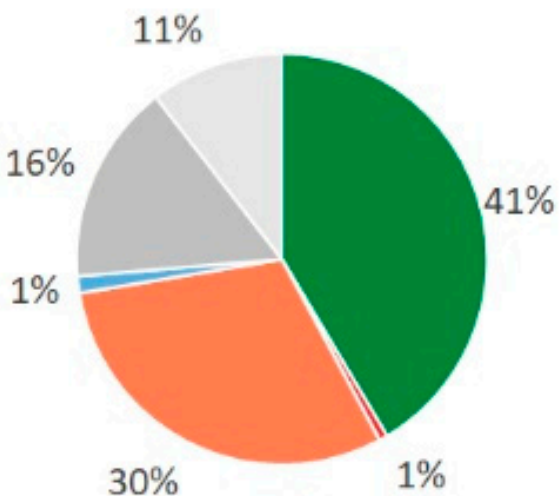

$\square+n+1-$

\section{Economic feasibility}

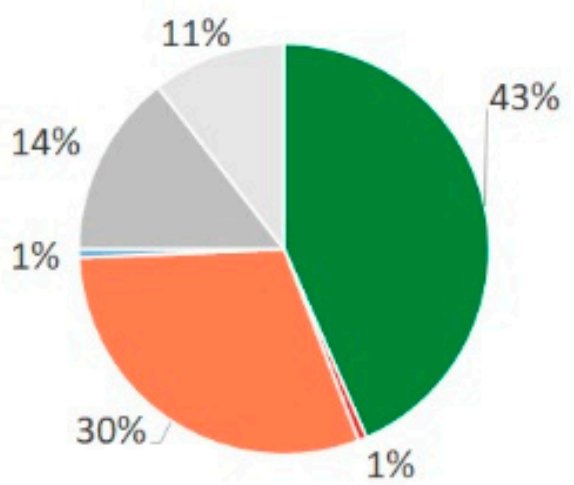

NA

Figure 14. Repartition of evaluation categories for the criteria of the "technical \& economic feasibility" ambit.

The NBSs analysed have mainly positive or neutral impact on the five criteria of the "environment" ambit (Figure 15). NBS impact is positive at $89 \%$ regarding "biodiversity" criteria, $76 \%$ regarding "vegetation" criteria, $41 \%$ regarding "landscape (green infrastructure)" criteria, $28 \%$ for "water" criteria, and $26 \%$ for "soil" criteria. No negative impacts of NBS on the five criteria have been reported, and $1 \%$ mixed impact have been reported only for "landscape (green infrastructure)" criteria.

For "society" ambit criteria (Figure 16), NBSs have mainly no impact on the criteria( $49 \%$ for "local community involvement and governance", $52 \%$ for "quality of liferecreational activities" and 60\% for "landscape heritage"). Twenty-eight percent of NBSs increase "quality of life-recreational activities areas", $20 \%$ involve stakeholders, whereas only $8 \%$ have a recognized positive impact on landscape heritage. Negative and mixed impacts are reported only for "local community involvement and governance" with $1 \%$ of NBS not involving stakeholders and 2\% of NBS not involving all the relevant stakeholders.

Finally, for the "local economy" ambits (Figure 17), assessments are similar for both criteria. Data are scarcely available in the literature cases: in $66 \%$ of cases the effects of NBS on the "local economy reinforcement" are unclear or unknown and in $68 \%$ of cases the effects of NBS on "revitalization of marginal areas" are unclear or unknown. For both criteria, almost a quarter of solutions (23\%) have no impact (neither positive nor negative). Only a few percent are reported to have a positive, negative or mixed impact on these criteria. Two percent of the NBS have mixed impact on both "revitalization of marginal areas" and "local economy reinforcement" criteria. Two percent have positive impact on "revitalization of marginal areas" and 3\% on "local economy reinforcement". Finally, 1\% of the NBS are reported to have negative impact on the "local economy reinforcement" criterion. 


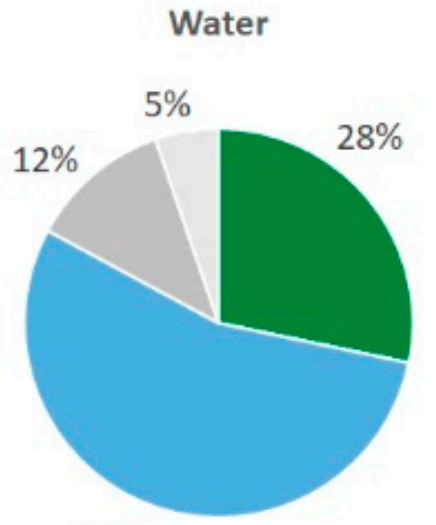

$55 \%$
Soil

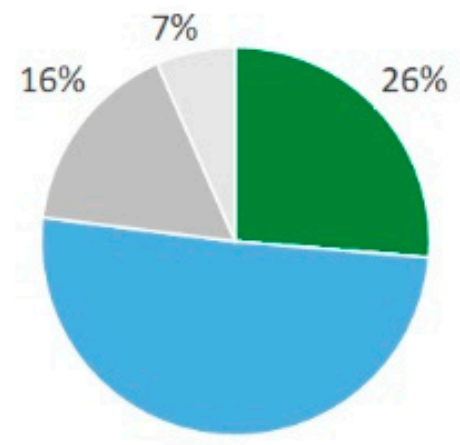

$51 \%$
Landscape

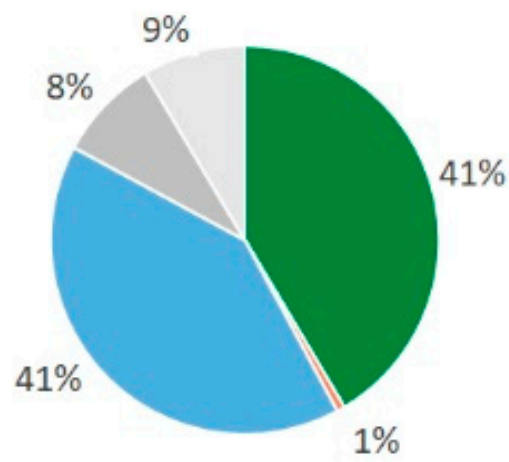

Biodiversity
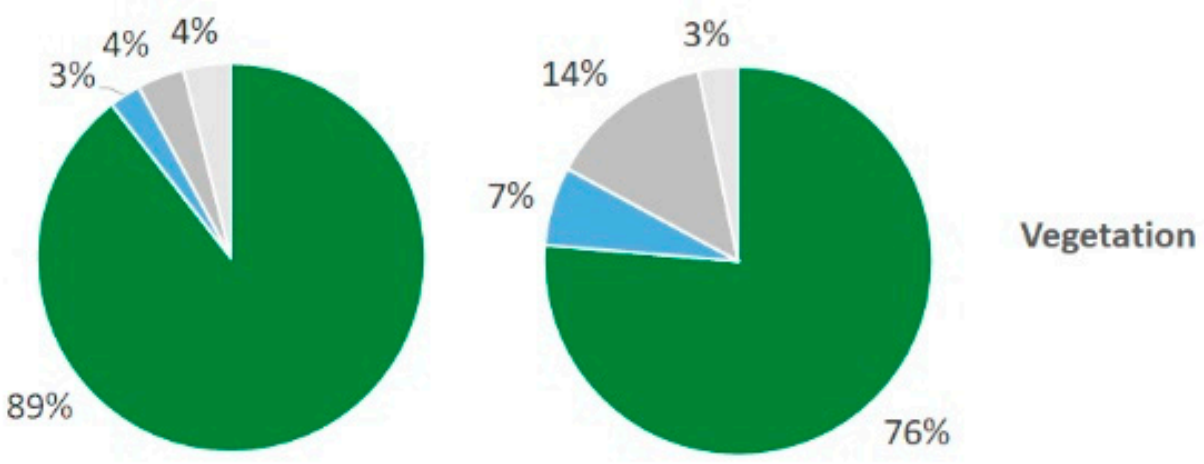

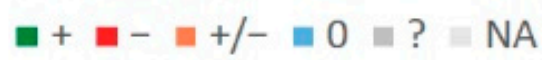

Figure 15. Repartition of evaluation categories for the criteria of the "environment" ambit.

Community involvement

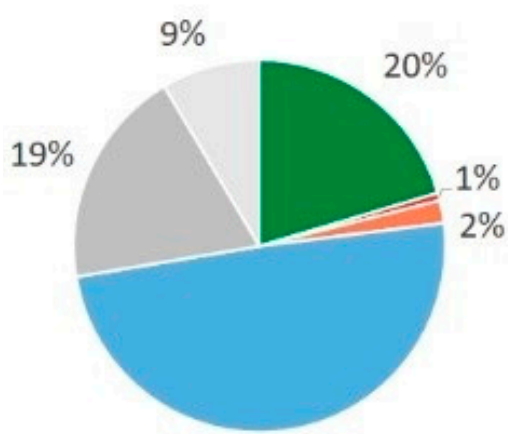

$49 \%$
Landscape heritage

$8 \%$

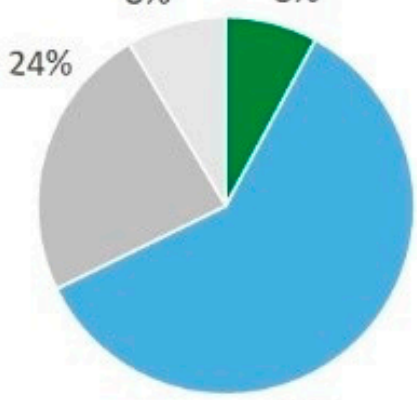

$60 \%$
Quality of life

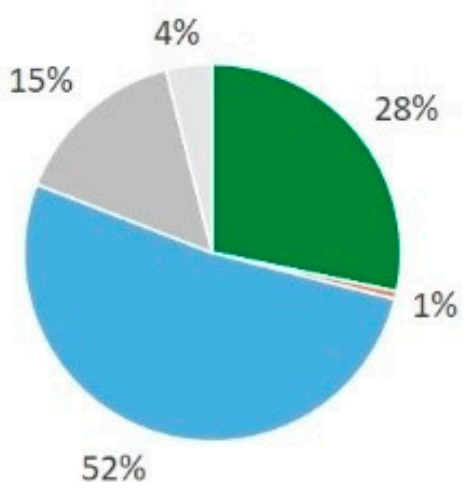

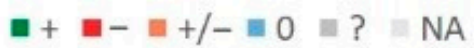

Figure 16. Repartition of evaluation categories for the criteria of the "society" ambit. 
Revitalization

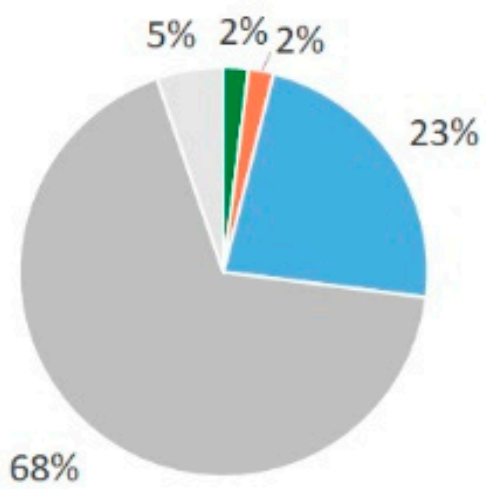

Local economy

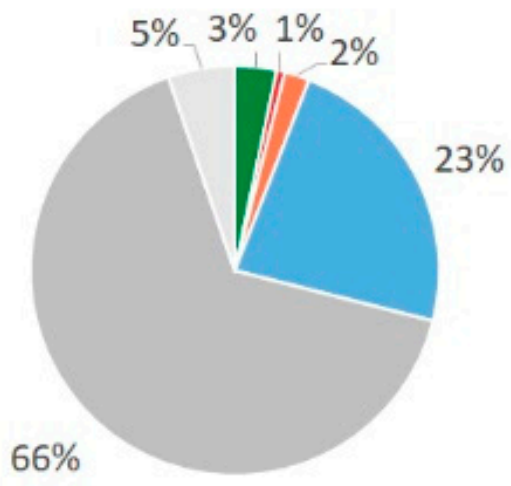

$$
\square+\square-\square+/-\square 0 \square \text { ? } \square \text { NA }
$$

Figure 17. Repartition of evaluation categories for the criteria of "local economy" ambit.

\section{Discussion \& Conclusions}

After the first literature and platform review, a first set of NBS cases focussing on hilly and mountainous areas were gathered. This first set of NBS cases was then enriched with feedback from Bavaria area cases to reach 152 NBS cases. Among the cases entered into the database, not all address directly hazards. Indeed, for almost half of the cases, the primary aim of the NBSs' implementation is linked to biodiversity and ecosystem conservation or restauration, and they will influence risk level only as co-benefit. In addition, while landslide and rock fall hazards are specific of mountainous areas, very few NBS cases target them (13), whereas many cases addressed floods (55). This is consistent with precedent reviews $[4,17]$.

The main difficulty encountered while inventorying the NBS case studies was to identify NBSs because NBS is a recent terminology and not all actions are labelled as "NBSs" $[4,6]$. In order to bypass such difficulties wider keywords were used such as "ecosystem-based" or "ecosystem services". Our study shows that it is difficult to identify many actions undertaken at local level without being labelled as NBSs. Some of them are at best disseminated in grey literature in local languages and in consequence hardly identifiable and for other generic principle is disseminated but no data are available on practical implementation cases. It is for example the case of Bavarian cases added to the database, which were available on municipalities' websites in German only.

The database frame of the PHUSICOS database was chosen as the best compromise to provide both detailed and standardized information. Indeed, inventories and databases reduce the precision of data available, by selecting potentially common fields. The scope of the database-NBSs for hydro-meteorological triggered events and environmental issues in hilly and mountainous areas - and the proposed assessment for five ambits and fifteen criteria constitute the innovation here. In addition, assessment criteria can be used to filter the database content, thus allowing stakeholders to browse the database according to NBS performance.

The analysis of the first assessment results shows that NBS generally perform very well regarding the five criteria of the "environment" ambit. This is particularly true for the "biodiversity" criteria, with almost $90 \%$ of positive rating. This result is not really surprising given the IUCN NBS definition stating that "Nature-based solutions are actions to protect, sustainably manage and restore natural and modified ecosystems in ways that address societal challenges effectively and adaptively, to provide both human well-being and biodiversity benefits" and it is also in phase with the conclusions of McVittie et al. [15]. When they address natural hazards, the database NBSs are also reported to perform relatively well regarding the three criteria of the "risk reduction" ambit (namely "hazard", "exposure" 
and "vulnerability") which is also underlined by other studies [10-13]. Nevertheless, the high proportion of unclear or unknown assessment stresses the lack of information regarding NBSs performance in the original studies, which is pointed out by Moos et al. [14]. Information is also lacking concerning "local economy" aspects, with at least two third unclear or unknown assessments. Additional efforts and studies are thus necessary to enhance the NBS performance evaluation regarding disaster risk reduction and to assess economical aspect taking into account environmental externalities [17]. The preliminary results also show that stakeholder engagement is not a strong point, whereas it is essential [14-16]. Finally, assessments are more contrasted regarding "economic and technical feasibility". Thus, these aspects may need extra attention when implementing NBSs.

In the future, the database will continue on evolving and the main big challenge will be to encourage the community to use the database as well as to contribute and to continuously enrich the database.

Author Contributions: Platform structure, A.B., M.G. and S.B.; methodology, A.B. and M.G.; validation, A.B. and M.G.; formal analysis, A.B. and M.G.; investigation, A.B.; writing—original draft preparation, A.B. and M.G.; project administration for BRGM, S.B. All authors have read and agreed to the published version of the manuscript.

Funding: PHUSICOS project received H2020 Grant Agreement No. 776681.

Institutional Review Board Statement: Not applicable.

Informed Consent Statement: Not applicable.

Data Availability Statement: Data available in a publicly accessible repository that does not issue DOIs. Publicly available datasets were analyzed in this study. This data can be found here: http:/ / phusicos.brgm.fr.

Acknowledgments: We would like to thank the 3 anonymous reviewers who helped us improved this work thanks to their valuable comments. We also would like to thank Olivier Frezot and Nicolas Guyot from BRGM for their technical support and the IT development of the platform; Amy Oen, Bjorn Kalsnes and other members of NGI team for the coordination of the PHUSICOS project; Aude Zingraff-Hamed, Gerd Lupp and Jonathan Schedler from TUM for implementation of many Bavarian cases into the database.

Conflicts of Interest: The authors declare no conflict of interest. The funders had no role in the design of the study; in the collection, analyses, or interpretation of data; in the writing of the manuscript, or in the decision to publish the results. 


\section{Appendix A}

Table A1. Services proposed by the reviewed platforms.

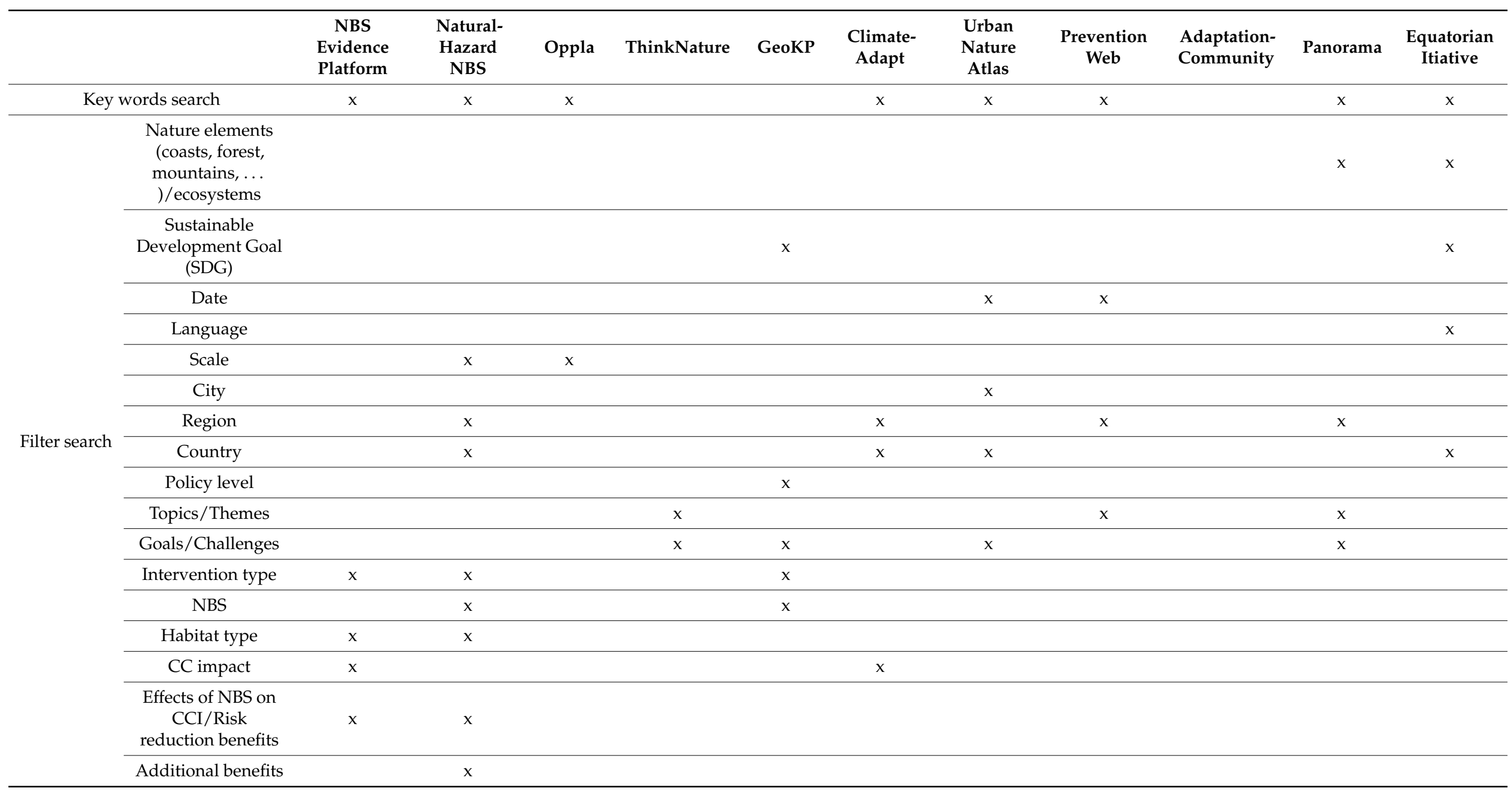


Table A1. Cont.

\begin{tabular}{|c|c|c|c|c|c|c|c|c|c|c|c|c|}
\hline & & $\begin{array}{l}\quad \text { NBS } \\
\text { Evidence } \\
\text { Platform }\end{array}$ & $\begin{array}{l}\text { Natural- } \\
\text { Hazard } \\
\text { NBS }\end{array}$ & Oppla & ThinkNature & GeoKP & $\begin{array}{l}\text { Climate- } \\
\text { Adapt }\end{array}$ & $\begin{array}{c}\text { Urban } \\
\text { Nature } \\
\text { Atlas }\end{array}$ & $\begin{array}{c}\text { Prevention } \\
\text { Web }\end{array}$ & $\begin{array}{l}\text { Adaptation- } \\
\text { Community }\end{array}$ & Panorama & $\begin{array}{l}\text { Equatorian } \\
\text { Itiative }\end{array}$ \\
\hline & Hazard & & $x$ & & & $x$ & & & $x$ & & & \\
\hline & $\begin{array}{c}\text { Type of data (qual. } \\
\text { Quant.) }\end{array}$ & $\mathrm{x}$ & & & & & & & & & & \\
\hline & $\begin{array}{c}\text { Type (NC \& ES } \\
\text { case study, NBS } \\
\text { project case study, } \\
\text { NBS city overview } \\
\text { case study) }\end{array}$ & & & $\mathrm{x}$ & & & & & & & & \\
\hline & Content type & & & & & & & $\mathrm{x}$ & $x$ & & & \\
\hline & Adaptation sector & & & & & & $x$ & & & & & \\
\hline & $\begin{array}{l}\text { Economic } \\
\text { cost/benefits } \\
\text { considered }\end{array}$ & $\mathrm{x}$ & & & & & & & & & & \\
\hline & $\begin{array}{l}\text { Status (ongoing, } \\
\text { completed,... ) }\end{array}$ & & $\mathrm{x}$ & & & & & & $\mathrm{x}$ & & & \\
\hline & Cost range & & US\$ & & & & & $€$ & & & & \\
\hline & Urban settings & & & & & & & $\mathrm{x}$ & & & & \\
\hline & $\begin{array}{l}\text { Management } \\
\text { set-up }\end{array}$ & & & & & & & $\mathrm{x}$ & & & & \\
\hline & $\begin{array}{l}\text { Type of financing } \\
\text { source }\end{array}$ & & & & & & & $\mathrm{x}$ & & & & \\
\hline & $\begin{array}{l}\text { Monitoring process } \\
\text { in place }\end{array}$ & & & & & & & $\mathrm{x}$ & & & & \\
\hline & $\begin{array}{l}\text { Citizen involved in } \\
\text { monitoring }\end{array}$ & & & & & & & $\mathrm{x}$ & & & & \\
\hline \multirow{2}{*}{ Display } & Heat map & $x$ & & & & & & & $\mathrm{x}$ & & $\mathrm{x}$ & \\
\hline & Map view & $x$ & $x$ & $x$ & $x$ & $x$ & & $x$ & & & & \\
\hline
\end{tabular}


Table A1. Cont.

\begin{tabular}{|c|c|c|c|c|c|c|c|c|c|c|c|c|}
\hline & & $\begin{array}{c}\text { NBS } \\
\text { Evidence } \\
\text { Platform }\end{array}$ & $\begin{array}{c}\text { Natural- } \\
\text { Hazard } \\
\text { NBS }\end{array}$ & Oppla & ThinkNature & GeoKP & $\begin{array}{l}\text { Climate- } \\
\text { Adapt }\end{array}$ & $\begin{array}{c}\text { Urban } \\
\text { Nature } \\
\text { Atlas }\end{array}$ & $\begin{array}{l}\text { Prevention } \\
\text { Web }\end{array}$ & $\begin{array}{l}\text { Adaptation- } \\
\text { Community }\end{array}$ & Panorama & $\begin{array}{l}\text { Equatorian } \\
\text { Itiative }\end{array}$ \\
\hline \multirow[b]{2}{*}{ Data } & NBS only & $x$ & $x$ & $x$ & $x$ & $x$ & & $x$ & & & $x$ & \\
\hline & $\begin{array}{c}\text { Number of case } \\
\text { studies }\end{array}$ & 303 & 186 & 292 & 112 & 94 & 106 & 1000 & & & 134 & 721 \\
\hline \multirow{2}{*}{$\begin{array}{l}\text { Sources } \\
\text { of data }\end{array}$} & Articles & $\mathrm{x}$ & & & & $x$ & $x$ & & & & & \\
\hline & Projects & & $\mathrm{x}$ & $\mathrm{x}$ & $\mathrm{x}$ & $\mathrm{x}$ & $\mathrm{x}$ & $x$ & & & & $x$ \\
\hline \multicolumn{2}{|c|}{ Download data } & Csv & Csv & & & & $\begin{array}{l}\text { Csv and } \\
\text { Tsv }\end{array}$ & & & & & \\
\hline \multirow{7}{*}{ Languages } & English & $\mathrm{x}$ & $\mathrm{x}$ & $\mathrm{x}$ & $\mathrm{x}$ & $\mathrm{x}$ & $\mathrm{x}$ & $x$ & & $\mathrm{x}$ & $x$ & $x$ \\
\hline & French & & & & & & & & & $x$ & $x$ & $x$ \\
\hline & Arabic & & & & & & & & & & & $x$ \\
\hline & Chinese & & & & & & & & & & & $\mathrm{x}$ \\
\hline & Spanish & & & & & & & & & & $x$ & $x$ \\
\hline & Portuguese & & & & & & & & & & & $x$ \\
\hline & Russian & & & & & & & & & & & $x$ \\
\hline \multicolumn{2}{|c|}{$\begin{array}{l}\text { Submit an entry and/or } \\
\text { crowdsourcing }\end{array}$} & & $x$ & & & $\mathrm{x}$ & & & & & $\mathrm{x}$ & \\
\hline
\end{tabular}


Table A1. Cont.

\begin{tabular}{|c|c|c|c|c|c|c|c|c|c|c|c|c|}
\hline & & $\begin{array}{c}\text { NBS } \\
\text { Evidence } \\
\text { Platform }\end{array}$ & $\begin{array}{l}\text { Natural- } \\
\text { Hazard } \\
\text { NBS }\end{array}$ & Oppla & ThinkNature & GeoKP & $\begin{array}{l}\text { Climate- } \\
\text { Adapt }\end{array}$ & $\begin{array}{c}\text { Urban } \\
\text { Nature } \\
\text { Atlas }\end{array}$ & $\begin{array}{l}\text { Prevention } \\
\text { Web }\end{array}$ & $\begin{array}{l}\text { Adaptation- } \\
\text { Community }\end{array}$ & Panorama & $\begin{array}{l}\text { Equatorian } \\
\text { Itiative }\end{array}$ \\
\hline \multirow{11}{*}{$\begin{array}{l}\text { Other } \\
\text { feature }\end{array}$} & $\begin{array}{l}\text { Projects and } \\
\text { platforms } \\
\text { catalogue }\end{array}$ & & & & $\mathrm{x}$ & & $\mathrm{x}$ & & & & & \\
\hline & Annual prize & & & & & & & & & & & $\mathrm{x}$ \\
\hline & e-learning & & & & & & & & & $x$ & & $x$ \\
\hline & Blog & & & & & & & & & & & $\mathrm{x}$ \\
\hline & Forum & & & $\mathrm{x}$ & & & & & & & & $x$ \\
\hline & FAQ & & & $\mathrm{x}$ & & & & $\mathrm{x}$ & & & & \\
\hline & Marketplace & & & $\mathrm{x}$ & & & & & & & & \\
\hline & e-library & & & & & & & & & $x$ & $x$ & $x$ \\
\hline & Multimedia centre & & & & $\mathrm{x}$ & & & & & $x$ & $x$ & $\mathrm{x}$ \\
\hline & Methodology & & & & & & & $\mathrm{x}$ & & & & \\
\hline & Webinar & & & & & & & & & $x$ & & \\
\hline
\end{tabular}




\section{Appendix B}

Table A2. Metadata used in the different databases.

\begin{tabular}{|c|c|c|c|c|c|c|c|c|c|c|c|}
\hline & & $\begin{array}{l}\quad \text { NBS } \\
\text { Evidence } \\
\text { Platform }\end{array}$ & $\begin{array}{l}\text { Natural- } \\
\text { Hazard } \\
\text { NBS }\end{array}$ & Oppla & ThinkNature & GeoKP & $\begin{array}{l}\text { Climate- } \\
\text { Adapt }\end{array}$ & $\begin{array}{l}\text { Urban } \\
\text { Nature Atlas }\end{array}$ & $\begin{array}{l}\text { Prevention } \\
\text { Web }\end{array}$ & Panorama & $\begin{array}{l}\text { Equator } \\
\text { Ianitiative }\end{array}$ \\
\hline \multirow{6}{*}{ Description } & Title & $\mathrm{x}$ & $\mathrm{x}$ & $x$ & $x$ & $x$ & $\mathrm{x}$ & $\mathrm{x}$ & $x$ & $x$ & $\mathrm{x}$ \\
\hline & Summary & $x$ & $\mathrm{x}$ & & $x$ & & & $x$ & & $x$ & $x$ \\
\hline & Objectives & & & $\mathrm{x}$ & $\mathrm{x}$ & $x$ & & & & & \\
\hline & Implementation activities & & & & $x$ & $x$ & & $\mathrm{x}$ & & & \\
\hline & $\begin{array}{c}\text { Type of data (qualitative, } \\
\text { quantitative, ... ) }\end{array}$ & $\mathrm{x}$ & & & & & & & & & \\
\hline & Category (green, grey, ... ) & & & & & $x$ & $\mathrm{x}$ & & & & \\
\hline \multirow{5}{*}{ Dates } & Date of publication/last edition & & & $x$ & & & $\mathrm{x}$ & & & $x$ & \\
\hline & $\begin{array}{l}\text { Date of project/NBS } \\
\text { implementation }\end{array}$ & & $\mathrm{x}$ & & $\mathrm{x}$ & & & & & & \\
\hline & $\begin{array}{c}\text { Project } \\
\text { duration/Implementation } \\
\text { time/Life time }\end{array}$ & & & & & & $\mathrm{x}$ & $\mathrm{x}$ & & & $\mathrm{x}$ \\
\hline & $\begin{array}{l}\text { Location (coordinates and/or } \\
\text { description) }\end{array}$ & & & $\mathrm{x}$ & $\mathrm{x}$ & $\mathrm{x}$ & & $\mathrm{x}$ & & $\mathrm{x}$ & $\mathrm{x}$ \\
\hline & City/area population & & & & & & & $x$ & & & \\
\hline \multirow{5}{*}{ Domain } & $\begin{array}{l}\text { Intervention (habitat created, } \\
\text { restauration, combination) }\end{array}$ & $\mathrm{x}$ & $x$ & & & $\mathrm{x}$ & & & & & \\
\hline & Ecosystem concerned & & & & & & & & & $\mathrm{x}$ & $\mathrm{x}$ \\
\hline & $\begin{array}{l}\text { Theme (adaptation, DRR, ... } \\
\text { )/Type of action/Keyword }\end{array}$ & & & $\mathrm{x}$ & $\mathrm{x}$ & & $\mathrm{x}$ & & & $x$ & $\mathrm{x}$ \\
\hline & $\begin{array}{l}\text { Hazard addressed/ } \\
\text { Climate impacts }\end{array}$ & $\mathrm{x}$ & $\mathrm{x}$ & & & $x$ & $\mathrm{x}$ & & & $\mathrm{x}$ & \\
\hline & Habitat & $x$ & & & & & & & & & \\
\hline
\end{tabular}


Table A2. Cont.

\begin{tabular}{|c|c|c|c|c|c|c|c|c|c|c|c|}
\hline & & $\begin{array}{l}\quad \text { NBS } \\
\text { Evidence } \\
\text { Platform }\end{array}$ & $\begin{array}{c}\text { Natural- } \\
\text { Hazard } \\
\text { NBS }\end{array}$ & Oppla & ThinkNature & GeoKP & $\begin{array}{l}\text { Climate- } \\
\text { Adapt }\end{array}$ & $\begin{array}{c}\text { Urban } \\
\text { Nature Atlas }\end{array}$ & $\begin{array}{l}\text { Prevention } \\
\text { Web }\end{array}$ & Panorama & $\begin{array}{l}\text { Equator } \\
\text { Ianitiative }\end{array}$ \\
\hline \multirow{10}{*}{ Evaluation } & Effects of NBS/NBS benefits & $\mathrm{x}$ & & & $\mathrm{x}$ & & & & & & \\
\hline & Ecosystem and social outcomes & $\mathrm{x}$ & & & & & & & & & \\
\hline & $\begin{array}{c}\text { Comparative effectiveness of } \\
\text { intervention? }\end{array}$ & $\mathrm{x}$ & & & & & & & & & \\
\hline & Report effect GHG mitigation? & $x$ & & & & & & & & & \\
\hline & $\begin{array}{c}\text { Non-experimental evaluation } \\
\text { done? }\end{array}$ & $\mathrm{x}$ & & & & & & & & & \\
\hline & $\begin{array}{l}\text { Does the study report economic } \\
\text { costs/benefits? }\end{array}$ & $\mathrm{x}$ & & & & & & & & & \\
\hline & risk reduction benefits & & $x$ & & & & & & & & \\
\hline & Additional benefits & & $\mathrm{x}$ & & & & & & & & \\
\hline & Success and limiting factors & & & $\mathrm{x}$ & & & $\mathrm{x}$ & & & & \\
\hline & $\begin{array}{c}\text { Impacts (on environment, } \\
\text { sustainable developments, ... ) }\end{array}$ & & & & $\mathrm{x}$ & & & $\mathrm{x}$ & & $\mathrm{x}$ & $\mathrm{x}$ \\
\hline \multirow{4}{*}{$\begin{array}{l}\text { International } \\
\text { classifica- } \\
\text { tion }\end{array}$} & Sustainable development goals & & & & & & & & & $\mathrm{x}$ & \\
\hline & Aichi targets & & & & & & & & & $\mathrm{x}$ & \\
\hline & Sendai Framework & & & & & & & & & $\mathrm{x}$ & \\
\hline & NDC submission & & & & & & & & & $\mathrm{x}$ & \\
\hline \multirow{4}{*}{ Challenges } & Urban settings & & & & & & & $\mathrm{x}$ & & & \\
\hline & Challenges & & & & & $\mathrm{x}$ & & $\mathrm{x}$ & & $\mathrm{x}$ & \\
\hline & Beneficiaries & & & & & & & $\mathrm{x}$ & & $\mathrm{x}$ & \\
\hline & Type of initiation organisation & & & & & & & $\mathrm{x}$ & & & $\mathrm{x}$ \\
\hline \multirow{3}{*}{ Media } & Pictures & & & & & & & $\mathrm{x}$ & & $\mathrm{x}$ & \\
\hline & Videos & & & & & & & & & $\mathrm{x}$ & \\
\hline & Story & & & & & & & & & $\mathrm{x}$ & \\
\hline
\end{tabular}


Table A2. Cont.

\begin{tabular}{|c|c|c|c|c|c|c|c|c|c|c|c|}
\hline & & $\begin{array}{c}\text { NBS } \\
\text { Evidence } \\
\text { Platform }\end{array}$ & $\begin{array}{c}\text { Natural- } \\
\text { Hazard } \\
\text { NBS }\end{array}$ & Oppla & ThinkNature & GeoKP & $\begin{array}{l}\text { Climate- } \\
\text { Adapt }\end{array}$ & $\begin{array}{c}\text { Urban } \\
\text { Nature Atlas }\end{array}$ & $\begin{array}{c}\text { Prevention } \\
\text { Web }\end{array}$ & Panorama & $\begin{array}{c}\text { Equator } \\
\text { Ianitiative }\end{array}$ \\
\hline \multirow{7}{*}{ Resources } & Contributed by & & & $\mathrm{x}$ & & & & & & $x$ & \\
\hline & Contributors (+ roles) & & & $x$ & $\mathrm{x}$ & & & $x$ & & $\mathrm{x}$ & \\
\hline & Resources & & & & & & & & & $x$ & \\
\hline & Sources/References & $x$ & & $x$ & $x$ & & $\mathrm{x}$ & $x$ & $x$ & & \\
\hline & Organisation involved & & & $\mathrm{x}$ & $\mathrm{x}$ & & & & & $x$ & $\mathrm{x}$ \\
\hline & Portals & & & & & & & & & $\mathrm{x}$ & \\
\hline & Related solutions & & & & & & $\mathrm{x}$ & & & & \\
\hline \multirow{3}{*}{ Finance } & Project cost (and benefits) & & $x$ & & & & $\mathrm{x}$ & $x$ & & & \\
\hline & Benefits & & $x$ & & & & & & & & \\
\hline & Financing sources/Donors & & $x$ & & $\mathrm{x}$ & & & & & & \\
\hline \multirow[t]{2}{*}{ Participation } & Community involvement & & & & & & $\mathrm{x}$ & & & & \\
\hline & Management set-up & & & & & & & $x$ & & & \\
\hline \multirow{6}{*}{ Others } & Legal aspects & & & & & & $\mathrm{x}$ & & & & \\
\hline & Awards & & & $\mathrm{x}$ & $\mathrm{x}$ & & & & & & \\
\hline & Comments & & & & & & & & & $\mathrm{x}$ & \\
\hline & Evolving & & & & & & & & & & \\
\hline & Contacts & & & & $x$ & & & & & & \\
\hline & Replication & & & & $x$ & & & & & & \\
\hline
\end{tabular}




\section{Appendix C}

Table A3. Close lists of answers.

\begin{tabular}{|c|c|}
\hline \multirow{9}{*}{ Ecosystems impacted } & Croplands \\
\hline & Grasslands \\
\hline & Heathlands and shrubs \\
\hline & Lakes \\
\hline & Mountains \\
\hline & Rivers \\
\hline & Urban areas \\
\hline & Wetlands \\
\hline & Woodlands and forests \\
\hline \multirow{8}{*}{ Hazards concerned } & Droughts \\
\hline & Erosion \\
\hline & Floods \\
\hline & Glacial retreat \\
\hline & Heat waves \\
\hline & Landslides \\
\hline & Rock falls \\
\hline & Snow avalanches \\
\hline \multirow{13}{*}{ Others challenges } & Biodiversity \\
\hline & Climate adaptation \\
\hline & Ecosystem conservation \\
\hline & Financing \\
\hline & Governance \\
\hline & Human well-being-recreational activities \\
\hline & Infrastructure \\
\hline & Job creation \\
\hline & Landscape and cultural heritage protection \\
\hline & Local communities involvement \\
\hline & Outreach \& communications \\
\hline & Restoration \\
\hline & Science and research \\
\hline
\end{tabular}


Table A3. Cont.

\begin{tabular}{|c|c|c|}
\hline \multirow{14}{*}{ Exposition } & \multirow{9}{*}{ Assets exposed } & Agriculture \\
\hline & & Urban or residential areas \\
\hline & & Industrial buildings \\
\hline & & Strategic buildings (hospitals, schools, ...) \\
\hline & & Roads \\
\hline & & Railways \\
\hline & & Lifelines \\
\hline & & No assets \\
\hline & & Unknown \\
\hline & \multirow{5}{*}{ Population exposed } & Yes, high density of population ( $>200$ persons $/ \mathrm{km}^{2}$ ) \\
\hline & & Yes, medium density of population (between 50 and 200 persons $/ \mathrm{km}^{2}$ ) \\
\hline & & Yes, low density of population $\left(<50\right.$ persons $\left./ \mathrm{km}^{2}\right)$ \\
\hline & & No \\
\hline & & Unknown \\
\hline \multirow{14}{*}{ Activity } & \multirow{5}{*}{ Job creation in NBS sector } & Yes, Over 10 \\
\hline & & Yes between 5 and 10 \\
\hline & & Yes, Less than 5 \\
\hline & & No jobs created \\
\hline & & Don't know \\
\hline & \multirow{5}{*}{$\begin{array}{l}\text { Job creation in tourism and } \\
\text { leisure sector }\end{array}$} & Yes, Over 10 \\
\hline & & Yes between 5 and 10 \\
\hline & & Yes, Less than 5 \\
\hline & & No jobs created \\
\hline & & Don't know \\
\hline & \multirow{4}{*}{ New/traditional activities increase } & Fishing \\
\hline & & Agriculture \\
\hline & & Others \\
\hline & & Unknown \\
\hline
\end{tabular}


Table A3. Cont.

\begin{tabular}{|c|c|c|}
\hline \multirow{21}{*}{$\begin{array}{l}\text { International } \\
\text { classification }\end{array}$} & \multirow{17}{*}{$\begin{array}{l}\text { Sustainable development } \\
\text { goals addressed }\end{array}$} & SDG1-No poverty \\
\hline & & SDG2-Zero Unger \\
\hline & & SDG3-Good Health and Well-being \\
\hline & & SDG4-Quality Education \\
\hline & & SDG5-Gender Equality \\
\hline & & SDG6-Clean Water and Sanitation \\
\hline & & SDG7-Affordable and Clean Energy \\
\hline & & SDG 8-Decent Work and Economy Growth \\
\hline & & SDG 9-Industry, Innovation and Infrastructure \\
\hline & & SDG 10-Reduced Inequality \\
\hline & & SDG 11—Sustainable Cities and Communities \\
\hline & & SDG 12-Responsible Consumption and Production \\
\hline & & SDG 13-Climate action \\
\hline & & SDG 14-Life below water \\
\hline & & SDG 15-Life on land \\
\hline & & SDG 16-Peace and Justice Strong institutions \\
\hline & & SDG 17-Partnerships to achieve the Goal \\
\hline & \multirow{9}{*}{$\begin{array}{c}\text { Sendai Framework priorities } \\
\text { addressed }\end{array}$} & Priority 1 . Understanding disaster risk \\
\hline & & Priority 2. Strengthening disaster risk governance to manage disaster risk \\
\hline & & Priority 3. Investing in disaster risk reduction for resilience \\
\hline & & $\begin{array}{l}\text { Priority 4. Enhancing disaster preparedness for effective response and to } \\
\text { "Build Back Better" in recovery, rehabilitation and reconstruction }\end{array}$ \\
\hline \multirow{10}{*}{$\begin{array}{l}\text { Temporal } \\
\text { aspects }\end{array}$} & & More than 10 years \\
\hline & & Between 5 and 10 years \\
\hline & & Between 2 and 5 years \\
\hline & & Less than 2 years \\
\hline & & Don't know \\
\hline & \multirow{5}{*}{ Implementation time of the action } & More than 10 years \\
\hline & & Between 5 and 10 years \\
\hline & & Between 2 and 5 years \\
\hline & & Less than 2 years \\
\hline & & Don't know \\
\hline \multirow{6}{*}{ Others } & \multirow{2}{*}{ Participatory processes } & Yes \\
\hline & & No \\
\hline & \multirow{4}{*}{ Transposition in a different context } & Yes, it is easily transposable \\
\hline & & Yes, but difficult to transpose \\
\hline & & No, it is site specific \\
\hline & & I don't know \\
\hline
\end{tabular}




\section{References}

1. Cramer, W.; Yohe, G.W.; Auffhammer, M.; Huggel, C.; Molau, U.; da Silva Dias, M.A.F.; Solow, A.; Stone, D.A.; Tibig, L. Detection and attribution of observed impacts. In Climate Change 2014: Impacts, Adaptation and Vulnerability. Part A: Global and Sectoral Aspects. Contribution of Working Group II to the Fifth Assessment Report of the Intergovernmental Panel on Climate Change; Cambridge University Press: Cambridge, UK; New York, NY, USA, 2014; pp. 979-1037.

2. Gariano, S.L.; Guzzetti, F. Landslides in a changing climate. Earth Sci. Rev. 2016, 162, 227-252. [CrossRef]

3. UCN French Committee. Nature-Based Solutions for Climate Change Adaptation and Disaster Risk Reduction; UCN French Committee: Paris, France, 2019.

4. Ruangpan, L.; Vojinovic, Z.; Di Sabatino, S.; Leo, L.S.; Capobianco, V.; Oen, A.M.P.; McClain, M.E.; Lopez-Gunn, E. Nature-based solutions for hydro-meteorological risk reduction: A state-of-the-art review of the research area. Nat. Hazards Earth Syst. Sci. 2020, 20, 243-270. [CrossRef]

5. Faivre, N.; Sgobbi, A.; Happaerts, S.; Raynal, J.; Schmidt, L. Translating the Sendai Framework into action: The EU approach to ecosystem-based disaster risk reduction. Int. J. Disaster Risk Reduct. 2018, 32, 4-10. [CrossRef]

6. Arce-Mojica, T.D.J.; Nehren, U.; Sudmeier-Rieux, K.; Miranda, P.J.; Anhuf, D. Nature-based solutions (NbS) for reducing the risk of shallow landslides: Where do we stand? Int. J. Disaster Risk Reduct. 2019, 41, 101293. [CrossRef]

7. Renaud, F.; Sudmeier-Rieux, K.; Estrella, M.; Nehren, U. Ecosystem-Based Disaster Risk Reduction and Adaptation in Practice; Springer: Cham, Switzerland, 2016; ISBN 978-3-319-43631-9.

8. Alves, A.; Vojinovic, Z.; Kapelan, Z.; Sanchez, A.; Gersonius, B. Exploring trade-offs among the multiple benefits of green-bluegrey infrastructure for urban flood mitigation. Sci. Total. Environ. 2020, 703, 134980. [CrossRef]

9. Caroppi, G.; Pugliese, F.; Gerundo, C.; De Paola, F.; Stanganelli, M.; Urciuoli, G.; Nadim, F.; Oen, A.M.P.; Andrés, P.; Giugni, M. A Comprehensive Framework Tool for NBS Performance Assessment. J. Flood Risk Manag. 2020. under review.

10. Bonnesoeur, V.; Locatelli, B.; Guariguata, M.R.; Ochoa-Tocachi, B.F.; Vanacker, V.; Mao, Z.; Stokes, A.; Mathez-Stiefel, S.-L. Impacts of forests and forestation on hydrological services in the Andes: A systematic review. For. Ecol. Manag. 2019, 433, 569-584. [CrossRef]

11. Casteller, A.; Häfelfinger, T.; Donoso, E.C.; Podvin, K.; Kulakowski, D.; Bebi, P. Assessing the interaction between mountain forests and snow avalanches at Nevados de Chillán, Chile and its implications for ecosystem-based disaster risk reduction. Nat. Hazards Earth Syst. Sci. 2018, 18, 1173-1186. [CrossRef]

12. Häyhä, T.; Franzese, P.P.; Paletto, A.; Fath, B.D. Assessing, valuing, and mapping ecosystem services in Alpine forests. Ecosyst. Serv. 2015, 14, 12-23. [CrossRef]

13. Kobayashi, Y.; Mori, A.S. The Potential Role of Tree Diversity in Reducing Shallow Landslide Risk. Environ. Manag. 2017, 59, 807-815. [CrossRef]

14. Moos, C.; Fehlmann, M.; Trappmann, D.; Stoffel, M.; Dorren, L. Integrating the mitigating effect of forests into quantitative rockfall risk analysis-Two case studies in Switzerland. Int. J. Disaster Risk Reduct. 2018, 32, 55-74. [CrossRef]

15. McVittie, A.; Cole, L.; Wreford, A.; Sgobbi, A.; Yordi, B. Ecosystem-based solutions for disaster risk reduction: Lessons from European applications of ecosystem-based adaptation measures. Int. J. Disaster Risk Reduct. 2018, 32, 42-54. [CrossRef]

16. Kumar, P.; Debele, S.E.; Sahani, J.; Aragão, L.; Barisani, F.; Basu, B.; Bucchignani, E.; Charizopoulos, N.; Di Sabatino, S.; Domeneghetti, A.; et al. Towards an operationalisation of nature-based solutions for natural hazards. Sci. Total. Environ. 2020, 731, 138855. [CrossRef] [PubMed]

17. Debele, S.E.; Kumar, P.; Sahani, J.; Marti-Cardona, B.; Mickovski, S.B.; Leo, L.S.; Porcù, F.; Bertini, F.; Montesi, D.; Vojinovic, Z.; et al. Nature-based solutions for hydro-meteorological hazards: Revised concepts, classification schemes and databases. Environ. Res. 2019, 179, 108799. [CrossRef] [PubMed]

18. Autuori, S.; Caroppi, G.; De Paola, F.; Giugni, M.; Pugliese, F.; Stanganelli, M.; Urciuoli, G. PHUSICOS Deliverable D4.1: Comprehensive Framework for NBS Assessment; European Commission: Brussels, Belgium, 2019; Available online: https:/ / phusicos. eu/wp-content/uploads/2019/05/D4.1_Task4.1_UNINA_14052019_Final_withAppendicies.pdf (accessed on 5 January 2020).

19. Nature-Based Solutions Evidence Platform. Available online: https:/ /www.naturebasedsolutionsevidence.info/ (accessed on 23 November 2020).

20. Natural Hazards Nature-Based Solutions. Available online: https:/ / naturebasedsolutions.org/ (accessed on 23 November 2020).

21. Oppla Case Study Database. Available online: https:/ / oppla.eu/case-study-finder (accessed on 23 November 2020).

22. ThinkNature Platform. 2020. Available online: https://www.think-nature.eu/ (accessed on 23 November 2020).

23. OPERANDUM Geol KP. Available online: http:/ / operandum.kajoservices.com/ (accessed on 23 November 2020).

24. Climate Adapt. Available online: http:/ / climate-adapt.eea.europa.eu (accessed on 23 November 2020).

25. Urban Nature Atlas. Available online: https:/ / naturvation.eu/atlas (accessed on 23 November 2020).

26. Prevention Web. Available online: http:/ / www.preventionweb.net (accessed on 23 November 2020).

27. AdaptationCommunity.Net. Available online: https://www.adaptationcommunity.net/fr/ (accessed on 23 November 2020).

28. Panorama Platform. Available online: https:/ / panorama.solutions/en (accessed on 23 November 2020).

29. Equatorian Initiative. Available online: https://www.equatorinitiative.org/ (accessed on 23 November 2020).

30. Acero, J.A.; Santa Coloma, O.; Albizu, M.; Castillo, C.; Barquin, M. Risk of Episodes in the Basque Country. In Proceedings of the 5th International Conference on Air Quality, Valencia, Spain, 29-31 March 2005; pp. 29-31. 
31. Acero, J.A.; Zeberio, U.; Azkune, S.; Santa Coloma, O. Air Quality Levels in the Basque Country (Spain): Source Contribution and Meteorology Influence. In Proceedings of the 6th International Conference on Urban Air Quality, Nicosia, Cyprus, 27-29 March 2007.

32. Acero, J.A.; Arrizabalaga, J.; Kupski, S.; Katzschner, L. Urban heat island in a coastal urban area in northern Spain. Theor. Appl. Climatol. 2013, 113, 137-154. [CrossRef]

33. Acero, J.A.; Arrizabalaga, J.; Kupski, S.; Katzschner, L. Deriving an Urban Climate Map in coastal areas with complex terrain in the Basque Country (Spain). Urban Clim. 2013, 4, 35-60. [CrossRef]

34. Acero, J.A.; Katzschner, L. Urban Climatic map studies in Spain, Bilbao. In The Urban Climatic Map A Methodology for Sustainable Urban Planning; Ng, E., Ren, C., Eds.; Routledge: London, UK, 2015; p. 528. ISBN 978-1-315-71761-6.

35. Allegretti, G.; Antunes, S. The Lisbon Participatory Budget: Results and Perspectives on an Experience in Slow but Continuous Transformation. J. Field Act. 2014, 11, 1-10.

36. Demetropoulou, L.; Nikolaidis, N.P.; Papadoulakis, V.; Tsakiris, K.; Koussouris, T.; Kalogerakis, N.; Koukaras, K.; Chatzinikolaou, A.; Theodoropoulos, K. Water framework directive implementation in Greece: Introducing participation in water governance-The Case of the Evrotas River Basin management plan. Environ. Policy Gov. 2010, 20, 336-349. [CrossRef]

37. Hellberg, M. Modeling Detention and Pollutant Fate in Bioretention Systems; Chalmers University of Technology: Göteborg, Sweden, 2016.

38. Mata, D. Lisbon's Green Plan Actions: Towards a Green City. In Proceedings of the Conference Urban Allotment Gardens in European Cities-Future, Challenges, and Lessons Learned, Lisbon, Portugal, 19-21 March 2014.

39. Millán, M.M.; Alonso, L.; Legarreta, J.A.; De Torrontegui, L.L.; Albizu, M.V.; Ureta, I.; Egusquiaguirre, C. A fumigation episode in an industrialized estuary: Bilbao, November 1981. Atmos. Environ. 1984, 18, 563-572. [CrossRef]

40. Millán, M.M.; Otamendi, E.; Alonso, L.; Ureta, I. Experimental Characterization of Atmospheric Diffusion in Complex Terrain with Land-Sea Interactions. JAPCA 1987, 37, 807-811. [CrossRef]

41. Nikolaidis, N.P.; Stamati, D.; Moraetis, D. Impact of Phytoremediation and Bank Erosion Control in the Minimization of Nitrate Loads to the River. Tech. Rep. 2008, 4, 68.

42. Oliveira, S.; Andrade, H.; Vaz, T. The cooling effect of green spaces as a contribution to the mitigation of urban heat: A case study in Lisbon. Build. Environ. 2011, 46, 2186-2194. [CrossRef]

43. Rytter, J.; Schonhowd, I. Monitoring, Mitigation, Management, The Groundwater Project-Safeguarding the World Heritage Site of Bryggen in Bergen; Riksantikvaren: Oslo, Norway, 2015; ISBN 978-82-7574-087-6.

44. Soares, A.L.; Rego, F.C.; McPherson, E.G.; Simpson, J.R.; Peper, P.J.; Xiao, Q. Benefits and costs of street trees in Lisbon, Portugal Urban For. Urban Green. 2011, 10, 69-78. [CrossRef]

45. Zorraquino, J. Datos y Comentarios Sobre la Contaminación del Aire en Erandio (Bilbao) en 1969; DYNA Ingenieria e Industria: Bilbao, Spain, 1971; pp. 19-29.

46. Baills, A.; Garcin, M.; Bulteau, T. Assessment of selected climate change adaptation measures for coastal areas. Ocean Coast. Manag. 2020, 185, 105059. [CrossRef]

47. Baills, A.; Grandjean, G.; Maspataud, A.; Ettinger, S.; Abad, J.; Dias, N.; Albris, K.; Hemmers, J.; Clegg, G.; Martucci, C. The ESPREssO Action Database: Collecting and assessing measures for disaster risk reduction and climate change adaptation. Int. J. Disaster Risk Reduct. 2020, 48, 101599. [CrossRef] 